\title{
The attitudes of Algerian students on Facebook: how are they constructed?
}

\begin{abstract}
Allal MOKEDDEM
University of Algiers 3, Faculty of Economics, Business and Management Science, Department of Management, Algiers, Algeria

mokeddem.allal@yahoo.fr

Received date:31 December 2020; Accepted date:21 June 2021; published date: 18 October 2021

Academic Editor: Nabil Mzoughi

Copyright (c) 2021. Allal MOKEDDEM. Distributed under Creative Commons Attribution 4.0 International CC-BY 4.0

Abstract

Facebook is recognized as a place of interaction between people seeking pleasure and professionals. In this regard, in order to investigate the attitude of users when exploring the blue environment, an online survey distributed to 89 students from the University of Algiers 3 in Algeria was carried out. The ultimate goal of the study is to analyze the behaviour of Algerian students on Facebook since the internet has become a crucial technology not only to strengthen social interaction but also to develop educational and business activities of universities. Therefore, three factors justify Algerian students' behavior on Facebook, namely, actions of protection and confidentiality; the daily activities carried out on Facebook, and the temporal circumstantial actions driving their attitude on Facebook. These actions revealed three fallouts: an affected academic or professional performance; complaints from relatives and friends following the abusive time spent on Facebook, and finally, the health consequences due to excessive and late connection on Facebook.
\end{abstract}

Keywords: Facebook, attitude, protection activities, daily activities, temporal activities.

\section{Introduction}

Undoubtedly, the world of Facebook is growing in terms of the number of users. At the start of the first quarter of 2020, the number soared to 2.6 billion monthly active users, an increase of $9.2 \%$ from early 2019, (JDN, 2020). However, the use of the Facebook network takes on another dimension beyond the social one.

Cite this Article as : Allal MOKEDDEM (2021), "The attitudes of Algerian students on Facebook : how are they constructed ?", Journal of Internet Social Networking \& Virtual Communities, Vol. 2021 (2021), Article ID 518860, DOI : 10.5171/2021.518860 
The informative dimension of Facebook has gained ground compared to other platforms as seen in its contribution in supporting the work of the global public health community in terms of ensuring that everyone has access to accurate information regarding the phenomenon of COVID-19. At this point, a COVID-19 data center has been developed by Facebook with the aim of providing real time information on the health situation (Facebook, 2020). In addition, Facebook has become the main hub for digital marketing. In figures, 1.47 billion people connect to Facebook every day (Facebook, 2019). This figure encourages companies and individuals to invest their resources over time and to transform their business strategies into a digital environment.

In Algeria, according to the Blog Medianet (2016), Facebook has 15 million users, or $37.8 \%$ of the population. According to estimates, $14 \%$ rely on entertainment and technology, $13.6 \%$ are projected for hobbies and various activities, and $12.2 \%$ for sports and outdoor activities. Therefore, behind these numbers, there is a collection of knowledge and attitudes towards actions taken by users. In this context, identifying attitudes can generate new needs, and therefore new business opportunities.

In this article, the author wants to explore what is hidden behind the world of Facebook especially in the purely conservative Arab world. The main objective is to analyze the attitude of Algerian students towards Facebook. This choice is due to academic and business reasons, since each university is looking for ways to market its future educational products by analyzing students' behaviours on Facebook and thus develop its future educational strategies by integrating the social dimension as a key factor of its strategy. For this reason, universities have an interest to know how students behave on Facebook on a daily basis.

This paper is divided as follows. The first part describes what is actually happening on Facebook and how it affects users' attitudes. The second part is purely practical, analyzing the attitude of the Algerian students and what are the rules that can be drawn behind each action taken by the user. In the last part, the empirical model that describes the attitude of Algerian students towards Facebook is discussed.

\section{Attitudes towards Facebook: what happens behind?}

Everyone knows Facebook as the most popular social network in the world. Facebook allows different user categories (students, professionals, bloggers, and influencers ...) to introduce themselves via shared profiles with their fans and friends. Facebook allows users to engage in various social activities (posting activities, building relationships...), educational (giving advice, leading conferences and presenting announcements and online training...), or cultural (hosting stages and shows, founding an online video library...). According to Padyab et al. (2016), the sharing process on Facebook depends on a set of factors such as trust in the site of the social network in question and especially the confidentiality of the disclosure of personal information. According to Debatin et al. (2009), some researchers have aroused the following concern: "Does what happens on Facebook stay on Facebook?"

In this context, the Organization of International Privacy Surveillance has accused Facebook of serious privacy breaches (Race to the Bottom, 2007). This memo is based on a mistrust of the process of data mining, transferring data to other companies, and collecting data from newspapers, blogs and instant messaging services.

In this context, using Facebook in blind mode is highly dangerous either for individuals or professionals. Social media are technological artefacts used by millions of users in different ways (Tartaglia, 2016). For some, like novices (teenagers), Facebook is seen as a vital network affecting their sense of themselves. This category sees Facebook as a space to 
compensate the social deficit due to low self-esteem. At this point, users are looking to assert themselves and replace their real personality with a virtual one. Fullwood et al. (2016) indicate that some users spend more time on Facebook seeking to increase the fewest friends existing on their Facebook list. This is achieved by using a virtual nickname that claims to have an important social capital. Others see Facebook as a good opportunity to express and collect relevant information to work on their personalities.

Users are affected by feedback from their peers who comment on their posts. This action can generate a positive attitude only if the comments are encouraging to such practices or it can generate a negative attitude if the comments are against the activities carried out. As a result, according to Halder and Khatun (2018), users feel depressed when spending more time on social media. This is due to the fact that the user is often linked to self-improvement images of others. This can cause mental damages to one's self, increasing the lack of self-confidence, the degree of loneliness and the negative mood towards the surrounding social context.

For adult learners, the mode of use and the purposes are different compared to adolescents. Adults seek to create buzz through news boards presented by small teasers and pictures (Schäfer, 2020). This intention to exploit social networks contributes to the development of a Snack news channel with an information flow that spreads on a large scale. At this point, the effect of such action on Facebook will gradually impact the user's mind. This will create different levels of understanding which will lead to different behaviours, attitudes and reactions.

For professionals, online social networks attract the attention of specialists. This is due to its social and psychological impact. In this regard, the activity of professionals on social networks is associated with legal and ethical constraints (Nyangeni et al., 2015; Ross and Myers, 2017). Professionals must be careful in their actions on social networks, as these actions could affect the reputation of the profession and the institution (Nason et al., 2018). Professionals presented by organizations benefits from social networks because they allow them to reach customers and visitors using social media as an advertising tool (Kent and Taylor, 2016). Consequently, customers have the opportunity to choose the highest quality and most suitable product based not only on manufacturers' announcements, but also on respondents' feedback.

In this regard, there are a few examples of some initiatives from organizations such as universities that offer advertising and communication programs that include courses on the social media platform (Childers and Levenshus, 2016). Social media have changed the process of the educational system (Trust et al., 2016). Learners acquire knowledge by sharing the experiences of others and increasing their professional knowledge (Shestak et al., 2020). Moreover, a study conducted at the level of Dutch elementary schools asserts that social networks have a positive effect on students' performance (Moolenaar et al., 2012). Parents are part of the academic community, so it has become easier for them to receive information about their children's performance. Mettle (2018), in his study, indicated that professional social networks are also present in the health sector. They often include video conferences on medical topics, recordings of surgical procedures and testing tasks. Finally, it is crucial to emphasize the importance of social networks in the process of sharing information about extreme situations such as natural disasters (earthquakes, tsunamis, tornadoes, floods) (Yates and Paquette, 2011), epidemics, technological disasters, air disasters and terrorist attacks (Stieglitz et al., 2018).

The variety and cultural diversity of Facebook users serve in leading to different behaviours and attitudes. An attitude is built on the basis of a thought, a background and a reflection that determine the positive or negative responses to the 
stimulus. Jordan et al. (2002) affirm that attitude is strongly linked to the Theory of Planned Behaviour (TPB). This is in order to identify the different modalities that lead to a change in behaviour. A variety of actions on Facebook can generate different attitudes. The author of this paper presents a set of more popular practical actions on Facebook that may affect the attitude of users: (Błachnio et al., 2016; Cvijikj et al., 2011; Anspach, 2017; Tran and Shcherbakov, 2016).

\section{Post style:}

The post style, defined by (1) status, i.e. text only, (2) photo, containing an uploaded photo, (3) link, representing a link to external URL, and (4) video, containing an uploaded video, can lead to different attitudes, relationships, emotions and commitments. For example, statements led by the conservative party in the UK elections focus more on negative issues such as Brexit, terrorism and national security. In return, the labor party focuses on positive issues, such as the promise of increased social spending (Gerbaudo et al., 2019).

\section{User interaction with the post:}

The interaction with the advertising content is defined by the user's interaction level through (1) the number of comments on individual posts, (2) number of likes, and (3) interaction duration. This can develop a variety of attitudes and reactions. According to Chin et al. (2015), a study conducted with Taiwanese undergraduate students indicates that students' interaction with Facebook's content via the "Like" button will induce different behaviours and levels of motivation such as:

- A hedonic motivation: Which is linked to playfulness, entertainment and pleasure.

- A utilitarian motivation: Which aims to change the user's attitude to take external expectations into account.

- A conformity motivation: Which refers to the phenomenon whereby a person, under the influence of a group, changes his/her attitude or opinion about something to follow the most popular opinion.

- An affiliate motivation: Which makes an action match friendly measures and social interactions. In this case, each user seeks how to have his actions approved while maintaining his interpersonal relationships in harmony with others.

\section{Leadership opinion:}

The notion of opinion leadership refers to an individual's ability to influence the attitude of other users. The opinion groups are the most influential groups in social systems (Nunes et al., 2018). At this point, opinion leaders have several experiences on how to disseminate positive information based on the most beneficial and innovative concepts. Conversely, negative information is more homogeneous with the most disadvantageous and less innovative concepts.

\section{Analysis of comments:}

Nothing happens by chance. Facebook's black box will also contribute to the diversion of user's attitudes towards niche markets that work in relation to the ideologies, beliefs of politicians and lobbies as in the case of natural language processing systems that analyze sentiments from textual contents used in opinion polls. In this regard, according to Tran and Shcherbakov (2016), two approaches have been used to analyze the behaviour of users on social networks. The first approach aims to analyze comments in real time. The second approach analyzes the data stored in batch mode.

The automatic intelligence processing systems provide the opportunity to process comments posted on social networks. The approach proposed by Tran and Shcherbakov (2016) is based on four important steps: I) transform comments to batches on the basis of a positive/negative/neutral classification, II) build a comparative model that detects the trend of comments and what it looks like 
compared to the current situation, III) understands how this situation will be developed based on pattern prediction, and IV) implement actions to follow the trajectory and evolution of attitudes for ideological purposes.

Today, with the arrival of artificial intelligence techniques, Facebook can guide the publication chain either to protect the human life (against diseases or suicides) (Facebook, 2018), or to eliminate abusive and dangerous contents. According to the Financial Times, in a statement that appeared in 2019, the predictive learning machines would detect and stop bullying, hate speech and other political violations before they spread over the network. For this purpose, Facebook has developed a multidisciplinary team specializing in psychology, sociology, machine learning and data analysis with the aim of developing algorithms that can automatically flag unwanted content on Facebook in order to avoid every negative attitude that affects the morale and behaviour of others.

\section{Privacy setting:}

Privacy is one of the basic human needs, giving people their identity, autonomy, and individuality (Jędruszczak, 2005). The exposure of privacy is a very sensitive issue that affects the morality of social network users. In this regard, according to Ibrahim et al. (2012), damage caused due to privacy concerns includes the unintentional exposure of personal information, such as the visibility of personal profiles. Faced with its confidentiality concerns, the number of confidentiality parameters has dropped from 15 to 8 confidentiality options. Currently, Facebook allows you to configure privacy settings for basic information and for each type of data based on groups of default profiles (for example, friends, friends with their friends, and members of the restricted network or everyone).

Consequently, protective actions, in terms of access to information will have repercussions on the user's psychology.
Indeed, users will be involved through their personal or professional ideas with others. In addition, users will be affected by the opinions of others due to their trust in this type of group. For this reason, Facebook explains how the protection and privacy procedure will affect the behaviour and attitude of users.

The direct consequence of the modification of confidentiality parameters will therefore modify the relations between the members, and in particular, the nature of the information and the data that will be shared. At this point, two factors are strongly affected (Fred Cavazza, 2010), the first is the social factor since the social circle will be disrupted following the appearance of new constraints of confidentiality. In this regard, the author therefore finds a set of parameters such as the phenomenon of avatarization of the members. Facebook offers the possibility to shape a character using the best facet of their profile. For example: a background avatar of a discussion group that describes the environment and the greenery. In this context, the user will be better placed to share his attitude and ecological opinions to the members of the group, introducing the illusion into the user's mind by the background avatar of the discussion group. This encourages the user to carry out his activities in a purely professional environment.

The second factor is presented by the privilege factor used in networks. The user posts photos in groups which will be seen by leaders as young, funny and dynamic. In this regard, a selection system will be deployed based on the best combination of behavioural targeting. This type of action develops in the user a sense of self. Consequently, this modality develops homogeneous attitudes and behaviours toward the gender and individual style involved in the network.

The attitude built when using social media won't come out of nowhere. Behind each action or decision hides a set of knowledge that will be strongly linked to the expectations of users and their social- 
demographic context. This is in order to analyze how attitudes will be constructed and to measure the type of popular actions carried out by users.

The cultural and social particularity of the Arab world, a very conservative world, makes the investigation and analysis of attitudes an extremely difficult procedure. Indeed, the originality of this study depends on the scarcity of the pre-existing studies, in particular, on the way in which the attitude of the user is conceived in the Arab context.

\section{Methodology}

A quantitative study was carried out measuring the attitude and mode of consumption of social networks in Algeria in order to build a psychometric model that interprets the behavioural scales of users on Facebook. An online survey, distributed in March 2020 to undergraduates at the University of Algiers 3, Faculty of Economics, Business and Management Science was conducted. For the survey, a random sample was selected, composing of 89 students who carry out face-to-face training in business management for the 2019-2020 academic years. The structure of the survey is subjected to a set of sections presented in the table below:

Table 1: data structure

\begin{tabular}{|c|c|c|}
\hline Sections & \multicolumn{2}{|c|}{ Variables and items } \\
\hline $\begin{array}{l}\text { Part 1: } \quad \text { Socio- } \\
\text { demographic }\end{array}$ & \multicolumn{2}{|c|}{ Gender, age, occupation, location } \\
\hline $\begin{array}{l}\text { Part 2: } \quad \text { Generic } \\
\text { information on Facebook }\end{array}$ & \multicolumn{2}{|c|}{$\begin{array}{l}\text { Cost of use, other media of interaction, media of use, how long of use } \\
\text { and style of activity. }\end{array}$} \\
\hline $\begin{array}{l}\text { Part 3: Attitude towards } \\
\text { Facebook }\end{array}$ & 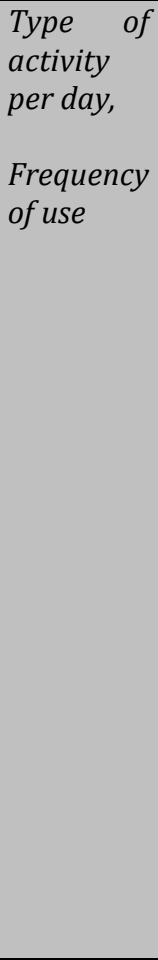 & $\begin{array}{l}\text { Look at your profile; chat with friends; } \\
\text { upload photos; search for people... etc. } \\
\text { Section 1: stay connected for a long time; } \\
\text { ignore household chores and work } \\
\text { duties; excited about Facebook; forming } \\
\text { new relationships; people are } \\
\text { complaining about the time you spend on } \\
\text { Facebook; negative impact on academic } \\
\text { and professional performance } \\
\text { Section 2: protection of your data; block } \\
\text { and replace any threats, person or } \\
\text { dangerous information; anticipation on } \\
\text { Facebook; life without Facebook would } \\
\text { be boring, empty and joyless; annoy you } \\
\text { if someone bothers you while using } \\
\text { Facebook; the risk of losing sleep. } \\
\text { Section 3: feel preoccupied when you are } \\
\text { not connected; try to reduce time on } \\
\text { Facebook; hidden behind the time you } \\
\text { spend on Facebook; spent more time } \\
\text { online instead of going out. }\end{array}$ \\
\hline
\end{tabular}

Source: Google Forms (see appendix)

Allal MOKEDDEM (2021), Journal of Internet Social Networking \& Virtual Communities, DOI : $10.5171 / 2021.518860$ 
The data structure has been subjected to data analysis processing under SPSS version 24.0 and Amos version 23.0. For this reason, the author made a set of assumptions listed in the following points:

o $\quad \mathrm{H}_{1}$ : There is a significant relationship between the different elements with regard to the different factors that measure "user attitude".

o $\mathrm{H}_{2}$ : There is a significant relationship between gender, occupation and location with respect to the type of activity performed per day.

o $\mathrm{H}_{3}$ : There is a significant relationship between gender, occupation and location with respect to the different items that measure "user attitude".

o $\mathrm{H}_{4}$ : There is a significant relationship between the user support and various items that measure "user attitude".

o $\mathrm{H}_{5}$ : There is a significant relationship between the cost of using social networks and the various items that measure "user attitude".

\section{Findings}

In order to investigate these assumptions, different analysis techniques were carried out. First, a validity and reliability test was presented to test the reliability of the measures selected in this study. Then, the author chose to extract the impact factors using an exploratory factor analysis technique. In the second phase, the author opted for a confirmatory factor analysis technique based on the test of goodness-offit statistics in order to approve hypothesis H1. The last phase of analysis is based on the Anova One Way test in order to approve the hypotheses H2, H3, H4 and H5.

\section{Reliability test:}

The instruments for measuring concepts refer to scales developed in the form of a Likert-type questionnaire. It can be seen that $100 \%$ of the 89 observations were found. This proves that there were no missing values in the database (See Table 2).

Table 2: summary of observation processing

\begin{tabular}{|c|c|c|}
\hline & $\mathbf{N}$ & $\mathbf{\%}$ \\
\hline Observations & & 100,0 \\
Valide & 89 &, 0 \\
Excluded & 0 & 100,0 \\
Total & & \\
\hline
\end{tabular}

Source (SPSS)

The following table shows the descriptive statistics for the 19 elements. It can be seen that all the items are measured on fivepoint scales with an average close to 2 . This means that the 89 participants are, on average, from time to time moderately integrated on Facebook through a set of activities presented in the discussion section (See table 3). 
Table 3: summary element statistics

\begin{tabular}{|c|c|c|c|c|c|c|c|}
\hline & $\begin{array}{c}\text { Averag } \\
\text { e }\end{array}$ & $\begin{array}{c}\text { Varian } \\
\text { ce }\end{array}$ & $\underset{\mathrm{m}}{\operatorname{Minimu}}$ & $\begin{array}{c}\text { Maximu } \\
\text { m }\end{array}$ & $\begin{array}{c}\text { Ban } \\
\text { d }\end{array}$ & $\begin{array}{c}\text { Maximum/Minim } \\
\text { um }\end{array}$ & $\begin{array}{l}\text { Numbe } \\
\text { r of } \\
\text { elemen } \\
\text { ts }\end{array}$ \\
\hline $\begin{array}{c}\text { Average } \\
\text { of } \\
\text { elements } \\
\text { Element } \\
\text { variance } \\
\text { Inter- } \\
\text { element } \\
\text { correlatio } \\
\text { ns }\end{array}$ & $\begin{array}{l}1,987 \\
, 991 \\
, 245\end{array}$ & $\begin{array}{l}108 \\
, 078 \\
, 017\end{array}$ & $\begin{array}{l}1,596 \\
, 438 \\
-, 052\end{array}$ & $\begin{array}{c}2,708 \\
1,401 \\
, 559\end{array}$ & $\begin{array}{c}1,11 \\
2 \\
, 963 \\
, 611\end{array}$ & $\begin{array}{c}1,697 \\
3,197 \\
-10,739\end{array}$ & $\begin{array}{l}19 \\
19 \\
19\end{array}$ \\
\hline
\end{tabular}

Source (SPSS)

Table 4 shows the value of the Cronbach's alpha index. It is noticeable here that the value of the Cronbach's alpha index is
0.859, which is excellent, because it exceeds the required minimum threshold of 0.70 (Nunnally, 1978).

Table 4: reliability statistics

\begin{tabular}{|c|c|c|}
\hline Cronbach's alpha & $\begin{array}{c}\text { Cronbach's alpha based on } \\
\text { standardized elements }\end{array}$ & $\begin{array}{c}\text { Number of } \\
\text { elements }\end{array}$ \\
\hline, 859 &, 861 & 19 \\
\hline
\end{tabular}

Source (SPSS)

\section{Explore the impact factors:}

An exploratory factor analysis technique was carried out in order to explore the factors that measure the attitudes of Algerian students towards Facebook. The latent variable was the subject of a set of measures (19 items) presented in the following table:

Table 5: descriptive statistics

\begin{tabular}{|l|c|c|}
\hline \multicolumn{1}{|c|}{ Items } & Average & $\begin{array}{c}\text { Standard } \\
\text { deviation }\end{array}$ \\
\hline BHV1: Stay on Facebook longer than expected. & 2,71 & 1,110 \\
\hline $\begin{array}{l}\text { BHV2: Neglect household chores, work chores or } \\
\text { university homework. }\end{array}$ & 1,89 &, 818 \\
\hline $\begin{array}{l}\text { BHV3: Prefer the excitement of Facebook to spend } \\
\text { time with your partner or best friends. }\end{array}$ & 2,18 & 1,173 \\
\hline BHV4: Form new relationships with a friend. & 1,75 &, 662 \\
\hline $\begin{array}{l}\text { BHV5: Other people in your life complain about your } \\
\text { time on Facebook. }\end{array}$ & 1,90 & 1,056 \\
\hline $\begin{array}{l}\text { BHV6: Your schoolwork or work suffer from the time } \\
\text { you spend on Facebook. }\end{array}$ & 1,78 &, 938 \\
\hline BHV7: Check your Facebook messages. & 2,60 & 1,165 \\
\hline $\begin{array}{l}\text { BHV8: Your academic (or professional) performance } \\
\text { suffer. }\end{array}$ & 1,60 &, 794 \\
\hline
\end{tabular}

Allal MOKEDDEM (2021), Journal of Internet Social Networking \& Virtual Communities, DOI : $10.5171 / 2021.518860$ 


\begin{tabular}{|l|c|c|}
\hline BHV9: Get defensive or secretive on Facebook. & 1,66 &, 865 \\
\hline $\begin{array}{l}\text { BHV10: Block disturbing thoughts about your life, } \\
\text { replace it with calming thoughts. }\end{array}$ & 1,99 & 1,028 \\
\hline BHV11: Anticipate when you go back online. & 2,03 & 1,005 \\
\hline $\begin{array}{l}\text { BHV12: Life without Facebook would be boring, } \\
\text { empty, and joyless. }\end{array}$ & 2,09 & 1,184 \\
\hline $\begin{array}{l}\text { BHV13: Slam, scream, or act in annoyance if someone } \\
\text { bothers you while you're on Facebook. }\end{array}$ & 1,73 &, 863 \\
\hline $\begin{array}{l}\text { BHV14: Lose sleep due to a late Facebook } \\
\text { connection. }\end{array}$ & 1,94 & 1,026 \\
\hline $\begin{array}{l}\text { BHV15: Feel concerned about Facebook when you } \\
\text { are not logged. }\end{array}$ & 1,82 & 1,121 \\
\hline $\begin{array}{l}\text { BHV16: Find yourself saying "just a few more } \\
\text { minutes" on Facebook. }\end{array}$ & 2,36 & 1,115 \\
\hline $\begin{array}{l}\text { BHV17: Try to cut down on the time you spend on } \\
\text { Facebook and fail. }\end{array}$ & 2,40 & 1,986 \\
\hline $\begin{array}{l}\text { BHV18: Try to hide nearby how long you've been on } \\
\text { Facebook. }\end{array}$ & 1,60 & $\begin{array}{l}\text { BHV19: Choose to spend more time on Facebook } \\
\text { rather than hanging out with others. }\end{array}$ \\
\hline
\end{tabular}

Source (SPSS)

The items presented are very well correlated. This was confirmed by the estimated KMO index of 0.765 , which is perhaps qualified as excellent. This confirms the good correlation between items. Then, the result of Bartlett's sphericity test is very significant $(\mathrm{p}$ value $=$
0.000) (See Table 6). Therefore, the author of this paper rejects the null hypothesis that his data come from a population whose matrix is an identity matrix. The correlations are therefore not all equal to zero. Therefore, this analysis can go forward.

Table 6: KMO index and Bartlett test

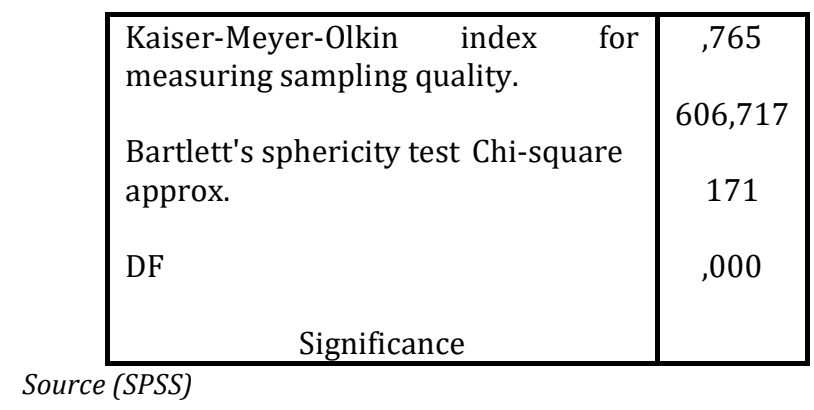

In the next step, the author explores the number of factors to extract. To do this, table 7 below is analyzed. It is found that in the second column, five factors (components) have a total VP greater than 1 , so, they are kept for analysis. The first factor alone explains $29.13 \%$ of the total variance among the 19 items selected for analysis. However, the five factors commonly explain $62.080 \%$ of the variance. In addition, the factors 6 to 19 do not explain enough variance. For this reason, they are not retained for the following steps (See Table 7).

Allal MOKEDDEM (2021), Journal of Internet Social Networking \& Virtual Communities, DOI: $10.5171 / 2021.518860$ 
Table 7: total variance explained

\begin{tabular}{|c|c|c|c|c|c|c|c|c|c|}
\hline \multirow[t]{2}{*}{$\begin{array}{c}\text { Compo } \\
\text { nent }\end{array}$} & \multicolumn{3}{|c|}{ Initial VP } & \multicolumn{3}{|c|}{$\begin{array}{l}\text { Sums extracted from } \\
\text { the load square }\end{array}$} & \multicolumn{3}{|c|}{$\begin{array}{c}\text { Sums of rotation of the } \\
\text { load square }\end{array}$} \\
\hline & $\begin{array}{l}\text { To } \\
\text { tal }\end{array}$ & $\begin{array}{c}\% \text { of } \\
\text { varia } \\
\text { nce }\end{array}$ & $\begin{array}{c}\% \\
\text { Cumul } \\
\text { ated }\end{array}$ & $\begin{array}{c}\text { Tota } \\
1\end{array}$ & $\begin{array}{c}\% \text { of } \\
\text { varia } \\
\text { nce }\end{array}$ & $\begin{array}{c}\% \% \\
\text { Cumul } \\
\text { ated }\end{array}$ & $\begin{array}{c}\text { Tota } \\
1\end{array}$ & $\begin{array}{c}\% \text { of } \\
\text { varia } \\
\text { nce }\end{array}$ & $\begin{array}{c}\% \% \\
\text { Cumul } \\
\text { ated }\end{array}$ \\
\hline 1 & 5,53 & 29,13 & 29,133 & $\begin{array}{c}5,53 \\
5\end{array}$ & $\begin{array}{c}29,13 \\
3\end{array}$ & 29,133 & $\begin{array}{c}2,95 \\
14\end{array}$ & $\begin{array}{c}15,53 \\
3\end{array}$ & 15,533 \\
\hline 2 & $\begin{array}{c}1,98 \\
0\end{array}$ & $\begin{array}{c}10,42 \\
1\end{array}$ & 39,554 & $\begin{array}{l}1,9 \\
80\end{array}$ & $\begin{array}{c}10,4 \\
21\end{array}$ & 39,554 & $\begin{array}{l}2,6 \\
63\end{array}$ & $\begin{array}{c}14,0 \\
17\end{array}$ & 29,551 \\
\hline 3 & $\begin{array}{c}1,60 \\
1\end{array}$ & 8,428 & 47,983 & $\begin{array}{c}1,60 \\
1\end{array}$ & 8,428 & 47,983 & $\begin{array}{c}2,62 \\
1\end{array}$ & $\begin{array}{c}13,79 \\
7\end{array}$ & 43,349 \\
\hline 4 & $\begin{array}{c}1,44 \\
5\end{array}$ & 7,606 & 55,590 & $\begin{array}{c}1,44 \\
5\end{array}$ & 7,606 & 55,590 & $\begin{array}{c}2,16 \\
3\end{array}$ & $\begin{array}{c}11,38 \\
4\end{array}$ & 54,734 \\
\hline 5 & $\begin{array}{c}1,23 \\
3\end{array}$ & 6,490 & 62,080 & $\begin{array}{c}1,23 \\
3\end{array}$ & 6,490 & 62,080 & $\begin{array}{c}1,39 \\
5\end{array}$ & 7,345 & 62,080 \\
\hline 6 & $\begin{array}{c}0,99 \\
5\end{array}$ & 5,236 & 67,317 & & & & & & \\
\hline 7 & $\begin{array}{c}0,86 \\
0\end{array}$ & 4,527 & 71,844 & & & & & & \\
\hline 8 & $\begin{array}{c}0,83 \\
2\end{array}$ & 4,381 & 76,225 & & & & & & \\
\hline 9 & $\begin{array}{c}0,69 \\
7\end{array}$ & 3,671 & 79,897 & & & & & & \\
\hline 10 & $\begin{array}{c}0,58 \\
8\end{array}$ & 3,096 & 82,994 & & & & & & \\
\hline 11 & $\begin{array}{c}0,55 \\
4\end{array}$ & 2,917 & 85,911 & & & & & & \\
\hline 12 & $\begin{array}{c}0,48 \\
6\end{array}$ & 2,561 & 88,473 & & & & & & \\
\hline 13 & $\begin{array}{c}0,45 \\
3\end{array}$ & 2,386 & 90,860 & & & & & & \\
\hline 14 & $\begin{array}{c}0,38 \\
0\end{array}$ & 2,002 & 92,863 & & & & & & \\
\hline 15 & $\begin{array}{c}0,35 \\
8\end{array}$ & 1,884 & 94,747 & & & & & & \\
\hline 16 & $\begin{array}{c}0,33 \\
0 \\
\end{array}$ & 1,738 & 96,486 & & & & & & \\
\hline 17 & $\begin{array}{c}0,24 \\
4\end{array}$ & 1,285 & 97,771 & & & & & & \\
\hline 18 & $\begin{array}{c}0,22 \\
2\end{array}$ & 1,172 & 98,944 & & & & & & \\
\hline 19 & $\begin{array}{c}0,20 \\
0\end{array}$ & 1,055 & 100 & & & & & & \\
\hline
\end{tabular}

Source (SPSS)

Allal MOKEDDEM (2021), Journal of Internet Social Networking \& Virtual Communities, 
Next, the author carried out a VARIMAX rotation in order to get a simpler factorial representation. This type of rotation preserves independence between factors. It is noted that the variables are much better distributed over the different factors. In addition, the difference between the correlations is greater after the rotation has been carried out. Thus, at least two variables were found to be part of a factor, and therefore, they can be kept to build scales (See Table 8).

Table 8: rotation of the component matrix

\begin{tabular}{|c|c|c|c|c|c|c|c|c|c|}
\hline \multicolumn{2}{|c|}{1} & \multicolumn{2}{|c|}{2} & \multicolumn{2}{|c|}{3} & \multicolumn{2}{|c|}{4} & \multicolumn{2}{|c|}{5} \\
\hline Items & Value & Items & Value & Items & Value & Items & Value & Items & Value \\
\hline BHV8 & ,579 & BHV3 & 696 & BHV14 & ,700 & BHV2 & ,734 & BHV1 &,- 495 \\
\hline BHV9 & ,674 & BHV4 & ,574 & BHV15 & ,749 & BHV6 & ,723 & BHV18 & ,811 \\
\hline BHV10 & ,787 & BHV5 & ,548 & BHV16 & 660 & & & & \\
\hline BHV11 & ,737 & BHV7 & ,728 & BHV17 & ,509 & & & & \\
\hline BHV12 & ,612 & & & BHV19 & ,645 & & & & \\
\hline BHV13 & ,584 & & & & & & & & \\
\hline
\end{tabular}

Extraction method: Principal component analysis.

Source (SPSS)

\section{Confirmatory factor analysis:}

A confirmatory factor analysis via Amos was carried out in order to validate the number of factors that contribute to the evaluation of the latent variable "user's attitude towards Facebook". The technique confirms that the five factors are adequate to better assess users' attitudes (See Figure 1).

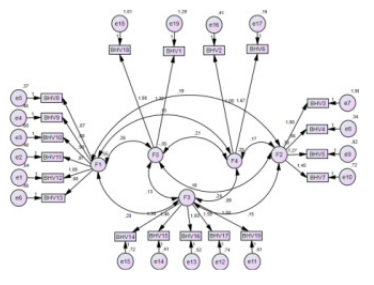

Fig 1. Model for estimating user behaviour towards Facebook

Source (Amos)

It is noted that all the factors strongly contribute to the process of analyzing the attitude of users towards Facebook with a $P$ value of less than $1 \%$. The estimates are presented in the first column (See table 9). In this case, at a time when the factor 1 increases by $1 \%$, the behaviour 11 increases by $97.3 \%$. The anticipation of the users when they reconnect to Facebook has a greater contribution to the composition of the first factor. Otherwise, the users have an attitude to anticipate on Facebook directly after their first reconnection to Facebook. 
Table 9: Regression weight estimates

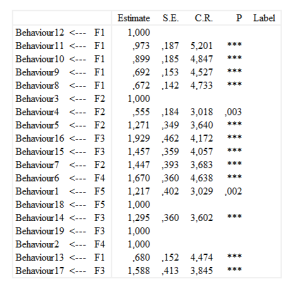

Source (Amos)

It is found that the expected change on each factor in the study has a significant impact on the other estimated factors. It is noted that the non-standardized covariance estimated between factors 1

\section{Table 11: Non-standardized covariances}

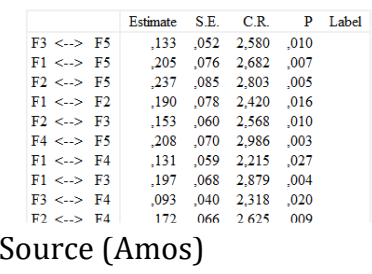

Assessment of the estimated quality of the model:

In the standards, CMIN/DF test represents an acceptable fit between the hypothetical model (Default Model) and the sample data. In other words, if the value of CMIN/DF is close to 0.00 , then the model is considered good. In addition, the values of the Comparative Fit Index (CFI), TuckerLewis coefficient (TLI), Incremental Fit Index (IFI), Relative Fit Index (RFI) and the Goodness of fit (GFI) are close to 1 , so the model has a very good fit. In the same time, the Root Mean Square Error of Approximation (RMSEA) has a value of
Table 10: Standardized regression

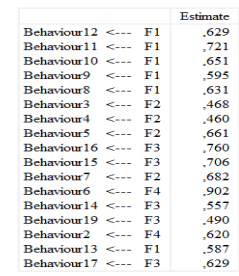

Source (Amos)

and 2 is measured in 0.190 with a significant correlation estimated at $47 \%$. In this regard, the variability of each element of factor 1 will affect the other factors of the same measure (See Tables 11 and 12).

Table 12 : Correlations

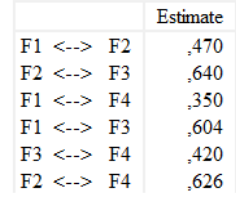

Source (Amos)

about 0.08 or less. This means that the approximation error is reasonable. In other words, the model has fewer errors in estimating the user's attitude when using the blue environment.

In this context, it is noted that the results are close to the references measurements presented above. This is with the impossibility to recover the standard errors which are in the modification indices pane due to the fact that the standard errors are coming from a different nature, i.e. resulting from different factors. Ultimately, this confirms that the estimated final model is good with

Allal MOKEDDEM (2021), Journal of Internet Social Networking \& Virtual Communities, DOI : $10.5171 / 2021.518860$ 
an estimated percentage of fit (GIF) of $80 \%$.

correct (See the results set in Table 13).

This proves that the hypothesis $\mathrm{H}_{1}$ is

Table 13: Measurement standards

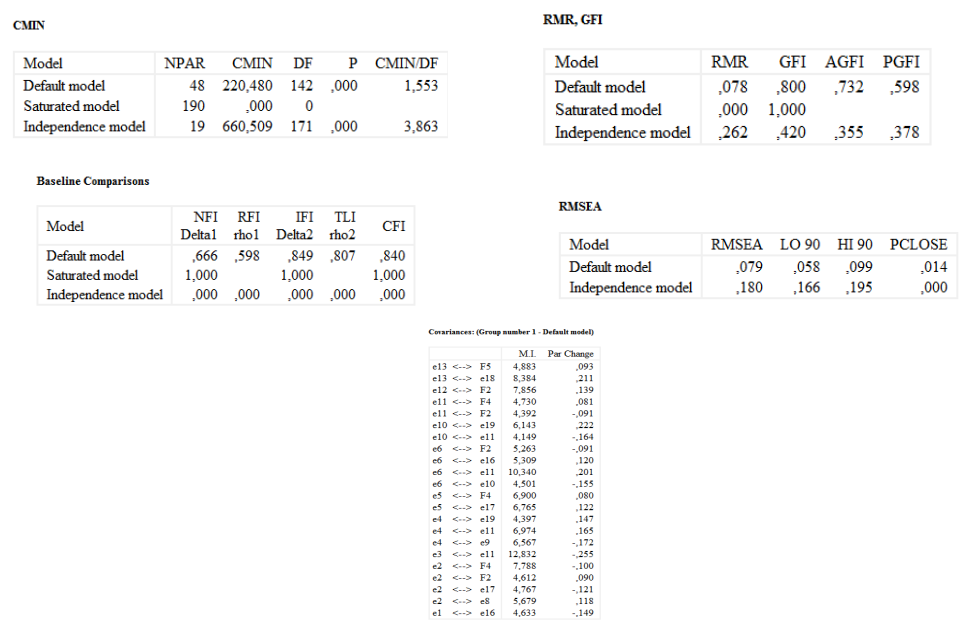

Source (Amos)

\section{Analysis of variance:}

This technique provides the opportunity to test the variability of grouping variables such as gender, occupation and location towards the type of activity and attitude of users towards Facebook. This allows measuring whether the type of activity and the user's attitude towards Facebook are different with respect to the demographic factors presented below.

Type of activity and gender:

It is important to verify the premise of variances equality with the Levene test. The author tests the hypothesis $\mathrm{H}_{0}$ in terms of whether the type of activity is similar with regard to gender (Male, Female).

Table 14: Homogeneity of variance test

\begin{tabular}{|l|c|c|c|c|}
\hline & $\begin{array}{c}\text { Levene } \\
\text { statistics }\end{array}$ & DF1 & DF2 & Sig. \\
\hline $\begin{array}{l}\text { Type of activity per day: Look at your } \\
\text { profile }\end{array}$ & 7,242 & 1 & 87 &, 009 \\
\hline $\begin{array}{l}\text { Type of activity per day: To chat with } \\
\text { friends }\end{array}$ & 1,171 & 1 & 87 &, 282 \\
\hline Type of activity per day: Upload photos & 2,392 & 1 & 87 &, 126 \\
\hline Type of activity per day: Search people &, 006 & 1 & 87 &, 937 \\
\hline $\begin{array}{l}\text { Type of activity per day: Read } \\
\text { comments posted on your wall }\end{array}$ &, 922 & 1 & 87 &, 340 \\
\hline $\begin{array}{l}\text { Type of activity per day: Read } \\
\text { comments on your photos }\end{array}$ &, 881 & 1 & 87 &, 350 \\
\hline Type of activity per day: To play games &, 306 & 1 & 87 &, 581 \\
\hline $\begin{array}{l}\text { Type of activity per day: Find } \\
\text { information about friends or others }\end{array}$ &, 887 & 1 & 87 &, 349 \\
\hline $\begin{array}{l}\text { Type of activity per day : Get updates } \\
\text { on friends' activities }\end{array}$ & 1,022 & 1 & 87 &, 315 \\
\hline
\end{tabular}

Source (SPSS)

Allal MOKEDDEM (2021), Journal of Internet Social Networking \& Virtual Communities, DOI: $10.5171 / 2021.518860$ 
For the first step, as the test is not significant ( $p>0.05)$ on all the variables except activity 1: "look at your profile". Therefore, the author can reject the null hypothesis of variances equality except for Activity 1 where the variance is heterogeneous (See Table 14).

This is perfect in allowing the author to move on to the interpretation of ANOVA.
From Table 15, the last column indicates that the probability of finding this value of $\mathrm{F}$ when the null hypothesis is true is greater than 0.05 , or more than $5 \%$. In this context, as the test is not significant ( $p>$ 0.05) on all the variables, then the gender factor is not a determining factor to describe the type of activity per day.

Table 15: ANOVA

\begin{tabular}{|c|c|c|c|c|c|c|}
\hline & & $\begin{array}{c}\text { Sum of } \\
\text { squares }\end{array}$ & $\begin{array}{l}\mathrm{D} \\
\mathrm{F}\end{array}$ & $\begin{array}{l}\text { Medium } \\
\text { square }\end{array}$ & $\mathrm{F}$ & Sig. \\
\hline \multirow[t]{3}{*}{$\begin{array}{l}\text { Type of activity per day: } \\
\text { Look at your profile }\end{array}$} & $\begin{array}{c}\text { Intergrou } \\
\text { ps }\end{array}$ & ,432 & 1 & ,432 & $\begin{array}{c}, 88 \\
6\end{array}$ & ,349 \\
\hline & $\begin{array}{c}\text { Intragrou } \\
\text { ps }\end{array}$ & 42,444 & 87 & ,488 & & \\
\hline & Total & 42,876 & 88 & & & \\
\hline \multirow[t]{3}{*}{$\begin{array}{l}\text { Type of activity per day: } \\
\text { To chat with friends }\end{array}$} & $\begin{array}{c}\text { Intergrou } \\
\text { ps }\end{array}$ & ,089 & 1 & ,089 & $\begin{array}{c}07 \\
5\end{array}$ & ,785 \\
\hline & $\begin{array}{c}\text { Intragrou } \\
\text { ps } \\
\end{array}$ & 103,731 & 87 & 1,192 & & \\
\hline & Total & 103,820 & 88 & & & \\
\hline \multirow[t]{3}{*}{$\begin{array}{l}\text { Type of activity per day: } \\
\text { Upload photos }\end{array}$} & $\begin{array}{c}\text { Intergrou } \\
\text { ps } \\
\end{array}$ & ,042 & 1 & ,042 & $\begin{array}{c}, 04 \\
5 \\
\end{array}$ & ,833 \\
\hline & $\begin{array}{c}\text { Intragrou } \\
\text { ps } \\
\end{array}$ & 80,453 & 87 & ,925 & & \\
\hline & Total & 80,494 & 88 & & & \\
\hline \multirow[t]{3}{*}{$\begin{array}{l}\text { Type of activity per day: } \\
\text { Search people }\end{array}$} & $\begin{array}{c}\text { Intergrou } \\
\text { ps }\end{array}$ & 685 & 1 & ,685 & $\begin{array}{l}2,0 \\
02\end{array}$ & 161 \\
\hline & $\begin{array}{c}\text { Intragrou } \\
\text { ps } \\
\end{array}$ & 29,765 & 87 & ,342 & & \\
\hline & Total & 30,449 & 88 & & & \\
\hline \multirow{3}{*}{$\begin{array}{l}\text { Type of activity per day: } \\
\text { Read comments posted on } \\
\text { your wall }\end{array}$} & $\begin{array}{c}\text { Intergrou } \\
\text { ps } \\
\end{array}$ & ,502 & 1 & ,502 & $\begin{array}{c}42 \\
1 \\
\end{array}$ & ,518 \\
\hline & $\begin{array}{c}\text { Intragrou } \\
\text { ps } \\
\end{array}$ & 103,857 & 87 & 1,194 & & \\
\hline & Total & 104,360 & 88 & & & \\
\hline \multirow{3}{*}{$\begin{array}{l}\text { Type of activity per day: } \\
\text { Read comments on your } \\
\text { photos }\end{array}$} & $\begin{array}{c}\text { Intergrou } \\
\text { ps }\end{array}$ & ,141 & 1 & , 141 & $\begin{array}{c}11 \\
5 \\
\end{array}$ & ,735 \\
\hline & $\begin{array}{c}\text { Intragrou } \\
\text { ps } \\
\end{array}$ & 106,960 & 87 & 1,229 & & \\
\hline & Total & 107,101 & 88 & & & \\
\hline $\begin{array}{l}\text { Type of activity per day: } \\
\text { To play games }\end{array}$ & $\begin{array}{c}\text { Intergrou } \\
\text { ps } \\
\end{array}$ & ,417 & 1 & ,417 & $\begin{array}{c}, 50 \\
5 \\
\end{array}$ & ,479 \\
\hline
\end{tabular}

Allal MOKEDDEM (2021), Journal of Internet Social Networking \& Virtual Communities, DOI : $10.5171 / 2021.518860$ 


\begin{tabular}{|l|c|c|c|c|c|c|}
\hline & $\begin{array}{c}\text { Intragrou } \\
\text { ps }\end{array}$ & 71,763 & 87 &, 825 & & \\
\cline { 2 - 7 } & Total & 72,180 & 88 & & & \\
\hline $\begin{array}{l}\text { Type of activity per day: } \\
\text { Find information about } \\
\text { friends or others }\end{array}$ & $\begin{array}{c}\text { Intergrou } \\
\text { ps }\end{array}$ &, 109 & 1 &, 109 &, 21 &, 648 \\
& $\begin{array}{c}\text { Intragrou } \\
\text { ps }\end{array}$ & 45,015 & 87 &, 517 & & \\
\cline { 2 - 7 } & Total & 45,124 & 88 & & & \\
\hline \multirow{2}{*}{$\begin{array}{l}\text { Type of activity per day: } \\
\text { Get updates on friends' } \\
\text { activities }\end{array}$} & $\begin{array}{c}\text { Intergrou } \\
\text { ps }\end{array}$ &, 562 & 1 &, 562 & 1,0 &, 318 \\
\cline { 2 - 7 } & $\begin{array}{c}\text { Intragrou } \\
\text { ps }\end{array}$ & 48,561 & 87 &, 558 & & \\
\hline & Total & 49,124 & 88 & & & \\
\hline
\end{tabular}

Source (SPSS)

\section{Type of activity and occupation:}

The premises of equality of variance are present for some items. In this context, the test is not significant ( $p>0.05)$ on all the variables, with the exception of three items, namely look at your profile, read comments posted on your wall and to play games on Facebook. The author cannot therefore reject the null hypothesis of equality variances except for activity 1; activity 5 and activity 7 where the variance is heterogeneous (See Table 16).

Table 16: Homogeneity of variance test

\begin{tabular}{|l|c|c|c|c|}
\hline & Levene & F1 & D & Sig. \\
statistics & $\mathbf{2}$ & \\
\hline $\begin{array}{l}\text { Type of activity per day: Look at your } \\
\text { profile }\end{array}$ & 4,727 & 1 & 87 &, 032 \\
\hline $\begin{array}{l}\text { Type of activity per day: To chat with } \\
\text { friends }\end{array}$ & 1,669 & 1 & 87 &, 200 \\
\hline Type of activity per day: Upload photos & 3,305 & 1 & 87 &, 072 \\
\hline Type of activity per day: Search people &, 343 & 1 & 87 &, 560 \\
\hline $\begin{array}{l}\text { Type of activity per day: Read } \\
\text { comments posted on your wall }\end{array}$ & 4,568 & 1 & 87 &, 035 \\
\hline $\begin{array}{l}\text { Type of activity per day: Read } \\
\text { comments on your photos }\end{array}$ & 3,422 & 1 & 87 &, 068 \\
\hline Type of activity per day: To play games & 4,323 & 1 & 87 &, 041 \\
\hline $\begin{array}{l}\text { Type of activity per day: Find } \\
\text { information about friends or others }\end{array}$ & 1,263 & 1 & 87 &, 264 \\
\hline $\begin{array}{l}\text { Type of activity per day: Get updates on } \\
\text { friends' activities }\end{array}$ & 1,662 & 1 & 87 &, 201 \\
\hline
\end{tabular}

Source (SPSS)

From Table 17, the last column indicates that the probability of finding this value of $\mathrm{F}$ when the null hypothesis is true is greater than 0.05 , or more than $5 \%$. In this case, the author has enough evidence to accept the null hypothesis and say that it is likely that the type of activity on Facebook is homogeneous according to occupation. However, there is an exception in two activities carried out on Facebook, namely "to chat with friends" and "upload photos" which vary in relation to the occupation, $68.5 \%$ presented by students and $31.5 \%$ presented by the category of civil servants.

Allal MOKEDDEM (2021), Journal of Internet Social Networking \& Virtual Communities, DOI: $10.5171 / 2021.518860$ 
Table 17: ANOVA

\begin{tabular}{|c|c|c|c|c|c|c|}
\hline & & $\begin{array}{c}\text { Sum of } \\
\text { squares }\end{array}$ & $\begin{array}{l}\mathrm{D} \\
\mathrm{F}\end{array}$ & $\begin{array}{l}\text { Medium } \\
\text { square }\end{array}$ & $\mathrm{F}$ & Sig \\
\hline \multirow[t]{3}{*}{$\begin{array}{l}\text { Type of activity per day: } \\
\text { Look at your profile }\end{array}$} & $\begin{array}{c}\text { Intergr } \\
\text { oups }\end{array}$ & ,774 & 1 & ,774 & 1,599 & $\begin{array}{c}20 \\
9\end{array}$ \\
\hline & $\begin{array}{c}\text { Intragr } \\
\text { oups }\end{array}$ & 42,102 & 87 & ,484 & & \\
\hline & Total & 42,876 & 88 & & & \\
\hline \multirow[t]{3}{*}{$\begin{array}{l}\text { Type of activity per day: To } \\
\text { chat with friends }\end{array}$} & $\begin{array}{c}\text { Intergr } \\
\text { oups }\end{array}$ & 7,830 & 1 & 7,830 & 7,097 & $\begin{array}{c}, 00 \\
9\end{array}$ \\
\hline & $\begin{array}{l}\text { Intragr } \\
\text { oups }\end{array}$ & 95,990 & 87 & 1,103 & & \\
\hline & Total & 103,820 & 88 & & & \\
\hline \multirow[t]{3}{*}{$\begin{array}{l}\text { Type of activity per day: } \\
\text { Upload photos }\end{array}$} & $\begin{array}{l}\text { Intergr } \\
\text { oups }\end{array}$ & 4,284 & 1 & 4,284 & 4,891 & $\begin{array}{c}, 03 \\
0 \\
\end{array}$ \\
\hline & $\begin{array}{l}\text { Intragr } \\
\text { oups }\end{array}$ & 76,210 & 87 & 876 & & \\
\hline & Total & 80,494 & 88 & & & \\
\hline \multirow[t]{3}{*}{$\begin{array}{l}\text { Type of activity per day: } \\
\text { Search people }\end{array}$} & $\begin{array}{l}\text { Intergr } \\
\text { oups }\end{array}$ & ,408 & 1 & ,408 & 1,181 & $\begin{array}{c}, 28 \\
0\end{array}$ \\
\hline & $\begin{array}{l}\text { Intragr } \\
\text { oups }\end{array}$ & 30,042 & 87 & ,345 & & \\
\hline & Total & 30,449 & 88 & & & \\
\hline \multirow{3}{*}{$\begin{array}{l}\text { Type of activity per day: } \\
\text { Read comments posted on } \\
\text { your wall }\end{array}$} & $\begin{array}{l}\text { Intergr } \\
\text { oups }\end{array}$ & ,285 & 1 & ,285 & ,238 & $\begin{array}{c}, 62 \\
7 \\
\end{array}$ \\
\hline & $\begin{array}{l}\text { Intragr } \\
\text { oups }\end{array}$ & 104,075 & 87 & 1,196 & & \\
\hline & Total & 104,360 & 88 & & & \\
\hline \multirow{3}{*}{$\begin{array}{l}\text { Type of activity per day: } \\
\text { Read comments on your } \\
\text { photos }\end{array}$} & $\begin{array}{l}\text { Intergr } \\
\text { oups }\end{array}$ & ,441 & 1 & ,441 & ,360 & $\begin{array}{c}, 55 \\
0 \\
\end{array}$ \\
\hline & $\begin{array}{l}\text { Intragr } \\
\text { oups }\end{array}$ & 106,660 & 87 & 1,226 & & \\
\hline & Total & 107,101 & 88 & & & \\
\hline \multirow[t]{3}{*}{$\begin{array}{l}\text { Type of activity per day: To } \\
\text { play games }\end{array}$} & $\begin{array}{l}\text { Intergr } \\
\text { oups }\end{array}$ & 2,400 & 1 & 2,400 & 2,992 & $\begin{array}{c}, 08 \\
7 \\
\end{array}$ \\
\hline & $\begin{array}{l}\text { Intragr } \\
\text { oups }\end{array}$ & 69,780 & 87 & ,802 & & \\
\hline & Total & 72,180 & 88 & & & \\
\hline \multirow{3}{*}{$\begin{array}{l}\text { Type of activity per day: Find } \\
\text { information about friends or } \\
\text { others }\end{array}$} & $\begin{array}{l}\text { Intergr } \\
\text { oups }\end{array}$ & ,480 & 1 & ,480 & ,935 & $\begin{array}{c}33 \\
6 \\
\end{array}$ \\
\hline & $\begin{array}{l}\text { Intragr } \\
\text { oups }\end{array}$ & 44,644 & 87 & ,513 & & \\
\hline & Total & 45,124 & 88 & & & \\
\hline \multirow[t]{2}{*}{$\begin{array}{l}\text { Type of activity per day: Get } \\
\text { updates on friends' activities }\end{array}$} & $\begin{array}{l}\text { Intergr } \\
\text { oups }\end{array}$ & 1,320 & 1 & 1,320 & 2,403 & $\begin{array}{c}12 \\
5 \\
\end{array}$ \\
\hline & Intragr & 47,803 & 87 & ,549 & & \\
\hline
\end{tabular}

Allal MOKEDDEM (2021), Journal of Internet Social Networking \& Virtual Communities, DOI : $10.5171 / 2021.518860$ 


\begin{tabular}{|l|l|l|l|l|l|l|}
\hline \multirow{2}{*}{} & oups & & & & & \\
\hline & Total & 49,124 & 88 & & & \\
\hline
\end{tabular}

\section{Type of activity and location:}

The premises of variance equality are present for all items with the exception of one item, namely "to play a game on
Facebook". In this context, the author cannot therefore reject the null hypothesis of the variances equality except for activity 7 where the variance is heterogeneous (See table 18).

Table 18: Homogeneity of variance test

\begin{tabular}{|l|c|c|c|c|}
\hline & $\begin{array}{c}\text { Levene } \\
\text { statistics }\end{array}$ & DF1 & DF2 & Sig. \\
\hline $\begin{array}{l}\text { Type of activity per day: Look at your } \\
\text { profile }\end{array}$ &, 297 & 1 & 87 &, 587 \\
\hline $\begin{array}{l}\text { Type of activity per day: To chat with } \\
\text { friends }\end{array}$ & 2,914 & 1 & 87 &, 091 \\
\hline $\begin{array}{l}\text { Type of activity per day: Upload } \\
\text { photos }\end{array}$ &, 284 & 1 & 87 &, 596 \\
\hline Type of activity per day: Search people &, 054 & 1 & 87 &, 817 \\
\hline $\begin{array}{l}\text { Type of activity per day: Read } \\
\text { comments posted on your wall }\end{array}$ & 2,896 & 1 & 87 &, 092 \\
\hline $\begin{array}{l}\text { Type of activity per day: Read } \\
\text { comments on your photos }\end{array}$ &, 026 & 1 & 87 &, 873 \\
\hline Type of activity per day: To play games & 4,997 & 1 & 87 &, 028 \\
\hline $\begin{array}{l}\text { Type of activity per day: Find } \\
\text { information about friends or others }\end{array}$ &, 033 & 1 & 87 &, 856 \\
\hline $\begin{array}{l}\text { Type of activity per day: Get updates } \\
\text { on friends' activities }\end{array}$ &, 086 & 1 & 87 &, 770 \\
\hline
\end{tabular}

Source (SPSS)

From Table 19, the last column indicates that the probability of finding this value of $\mathrm{F}$ when the null hypothesis is true is greater than 0.05 , or more than $5 \%$. In this case, the author has enough evidence to accept the null hypothesis and say that it is likely that the type of activity on Facebook is homogeneous according to the location distributed in two distinct places: $84.3 \%$ located in downtown and $15.7 \%$ located far from the city center.

Table 19: ANOVA

\begin{tabular}{|c|c|c|c|c|c|c|}
\hline & & $\begin{array}{c}\text { Sum of } \\
\text { squares }\end{array}$ & DF & $\begin{array}{l}\text { Medium } \\
\text { square }\end{array}$ & $\mathbf{F}$ & Sig. \\
\hline \multirow[t]{3}{*}{$\begin{array}{l}\text { Type of activity per day: Look at } \\
\text { your profile }\end{array}$} & $\begin{array}{c}\text { Intergro } \\
\text { ups }\end{array}$ & ,173 & 1 & ,173 & \multirow{3}{*}{$\begin{array}{c}, 35 \\
2\end{array}$} & \multirow[t]{3}{*}{,555 } \\
\hline & $\begin{array}{l}\text { Intragro } \\
\text { ups }\end{array}$ & 42,704 & 87 & \multirow[t]{2}{*}{,491 } & & \\
\hline & Total & 42,876 & 88 & & & \\
\hline \multirow[t]{2}{*}{$\begin{array}{l}\text { Type of activity per day: To chat } \\
\text { with friends }\end{array}$} & $\begin{array}{c}\text { Intergro } \\
\text { ups }\end{array}$ & 1,816 & 1 & 1,816 & \multirow{2}{*}{$\begin{array}{l}1,5 \\
49\end{array}$} & \multirow[t]{2}{*}{ 217 } \\
\hline & $\begin{array}{c}\text { Intragro } \\
\text { ups }\end{array}$ & 102,004 & 87 & 1,172 & & \\
\hline
\end{tabular}

Allal MOKEDDEM (2021), Journal of Internet Social Networking \& Virtual Communities, DOI: $10.5171 / 2021.518860$ 


\begin{tabular}{|c|c|c|c|c|c|c|}
\hline & Total & 103,820 & 88 & & & \\
\hline \multirow[t]{3}{*}{$\begin{array}{l}\text { Type of activity per day: Upload } \\
\text { photos }\end{array}$} & $\begin{array}{l}\text { Intergro } \\
\text { ups }\end{array}$ & ,091 & 1 & ,091 & \multirow{3}{*}{$\begin{array}{c}, 09 \\
8\end{array}$} & \multirow[t]{3}{*}{,755 } \\
\hline & $\begin{array}{l}\text { Intragro } \\
\text { ups }\end{array}$ & 80,404 & 87 & \multirow[t]{2}{*}{,924 } & & \\
\hline & Total & 80,494 & 88 & & & \\
\hline \multirow[t]{3}{*}{$\begin{array}{l}\text { Type of activity per day: Search } \\
\text { people }\end{array}$} & $\begin{array}{c}\text { Intergro } \\
\text { ups }\end{array}$ & ,306 & 1 & ,306 & \multirow{3}{*}{$\begin{array}{c}, 88 \\
2\end{array}$} & \multirow[t]{3}{*}{,350 } \\
\hline & $\begin{array}{c}\text { Intragro } \\
\text { ups }\end{array}$ & 30,144 & 87 & ,346 & & \\
\hline & Total & 30,449 & 88 & & & \\
\hline \multirow[t]{3}{*}{$\begin{array}{l}\text { Type of activity per day: Read } \\
\text { comments posted on your wall }\end{array}$} & $\begin{array}{c}\text { Intergro } \\
\text { ups }\end{array}$ & 116 & 1 & ,116 & \multirow{3}{*}{$\begin{array}{c}, 09 \\
7\end{array}$} & \multirow[t]{3}{*}{,757 } \\
\hline & $\begin{array}{c}\text { Intragro } \\
\text { ups }\end{array}$ & 104,244 & 87 & 1,198 & & \\
\hline & Total & 104,360 & 88 & & & \\
\hline \multirow[t]{3}{*}{$\begin{array}{l}\text { Type of activity per day: Read } \\
\text { comments on your photos }\end{array}$} & $\begin{array}{l}\text { Intergro } \\
\text { ups }\end{array}$ & ,000 & 1 & ,000 & \multirow{3}{*}{$\begin{array}{c}, 00 \\
0\end{array}$} & \multirow[t]{3}{*}{ 991 } \\
\hline & $\begin{array}{c}\text { Intragro } \\
\text { ups }\end{array}$ & 107,101 & 87 & 1,231 & & \\
\hline & Total & 107,101 & 88 & & & \\
\hline \multirow[t]{3}{*}{$\begin{array}{l}\text { Type of activity per day: To play } \\
\text { games }\end{array}$} & $\begin{array}{l}\text { Intergro } \\
\text { ups }\end{array}$ & 1,636 & 1 & 1,636 & \multirow{3}{*}{$\begin{array}{l}2,0 \\
18\end{array}$} & \multirow[t]{3}{*}{ 159 } \\
\hline & $\begin{array}{c}\text { Intragro } \\
\text { ups }\end{array}$ & 70,544 & 87 & ,811 & & \\
\hline & Total & 72,180 & 88 & & & \\
\hline \multirow{3}{*}{$\begin{array}{l}\text { Type of activity per day: Find } \\
\text { information about friends or } \\
\text { others }\end{array}$} & $\begin{array}{l}\text { Intergro } \\
\text { ups }\end{array}$ & 195 & 1 & ,195 & \multirow{3}{*}{$\begin{array}{c}, 37 \\
8\end{array}$} & \multirow[t]{3}{*}{, 540} \\
\hline & $\begin{array}{c}\text { Intragro } \\
\text { ups }\end{array}$ & 44,929 & 87 & ,516 & & \\
\hline & Total & 45,124 & 88 & & & \\
\hline \multirow[t]{3}{*}{$\begin{array}{l}\text { Type of activity per day: Get } \\
\text { updates on friends' activities }\end{array}$} & $\begin{array}{l}\text { Intergro } \\
\text { ups }\end{array}$ & ,537 & 1 & ,537 & \multirow{3}{*}{$\begin{array}{c}, 96 \\
1\end{array}$} & \multirow[t]{3}{*}{,330 } \\
\hline & $\begin{array}{c}\text { Intragro } \\
\text { ups }\end{array}$ & 48,587 & 87 & \multirow[t]{2}{*}{,558 } & & \\
\hline & Total & 49,124 & 88 & & & \\
\hline
\end{tabular}

Source (SPSS)

\section{Attitude towards Facebook broken down by gender, occupation and location:}

The premises of variance equality are present for some items with the exception of the following items: BHV10 is broken down according to gender, and the items BHV3, BHV6 and BHV7 are broken down in relation to the user's occupation. Finally, two items, BHV8 and BHV11, are broken down according to location. In this context, as the test is not significant ( $p>0.05)$ on all the variables, with the exception of the items presented above, the author cannot therefore reject the null hypothesis of the variances equality except for BHV10, BHV3, BHV6, BHV7, BHV8 and BHV11 where the variance is heterogeneous (See table 20). 
Table 20: Homogeneity of variance test

\begin{tabular}{|c|c|c|c|c|c|c|c|c|c|c|c|c|}
\hline & \multicolumn{4}{|c|}{ Gender } & \multicolumn{4}{|c|}{ Occupation } & \multicolumn{4}{|c|}{ Location } \\
\hline & $\begin{array}{c}\text { Levene } \\
\text { statistics }\end{array}$ & $\begin{array}{c}\mathrm{DF} \\
1\end{array}$ & $\begin{array}{c}\mathrm{D} \\
\mathrm{F} 2\end{array}$ & Sig. & $\begin{array}{c}\text { Levene } \\
\text { statistics }\end{array}$ & $\begin{array}{c}\mathrm{DF} \\
1\end{array}$ & DF2 & Sig. & $\begin{array}{c}\text { Levene } \\
\text { statistics }\end{array}$ & DF1 & DF2 & Sig. \\
\hline $\begin{array}{l}\text { BHV } \\
1 \\
\end{array}$ & ,952 & 1 & 87 & $\begin{array}{c}, 33 \\
2 \\
\end{array}$ & 1,905 & 1 & 87 & $\begin{array}{c}17 \\
1 \\
\end{array}$ & 604, & 1 & 87 & ,439 \\
\hline $\begin{array}{l}\text { BHV } \\
2 \\
\end{array}$ & ,399 & 1 & 87 & $\begin{array}{c}52 \\
9 \\
\end{array}$ & ,011 & 1 & 87 & $\begin{array}{c}91 \\
6 \\
\end{array}$ & ,097 & 1 & 87 & ,756 \\
\hline $\begin{array}{l}\text { BHV } \\
3\end{array}$ & ,097 & 1 & 87 & $\begin{array}{c}75 \\
6\end{array}$ & 9,624 & 1 & 87 & $\begin{array}{c}, 00 \\
3\end{array}$ & 1,954 & 1 & 87 & 166 \\
\hline $\begin{array}{l}\mathrm{BHV} \\
4 \\
\end{array}$ & ,031 & 1 & 87 & $\begin{array}{c}, 86 \\
1 \\
\end{array}$ & ,004 & 1 & 87 & $\begin{array}{c}95 \\
1 \\
\end{array}$ & 139 & 1 & 87 & 711 \\
\hline $\begin{array}{l}\text { BHV } \\
5\end{array}$ & ,134 & 1 & 87 & $\begin{array}{c}71 \\
5\end{array}$ & 3,399 & 1 & 87 & $\begin{array}{c}, 06 \\
9\end{array}$ & ,525 & 1 & 87 & 471 \\
\hline $\begin{array}{l}\text { BHV } \\
6\end{array}$ & 3,735 & 1 & 87 & $\begin{array}{c}, 05 \\
7\end{array}$ & 5,467 & 1 & 87 & $\begin{array}{c}, 02 \\
2\end{array}$ & 093 & 1 & 87 & 761 \\
\hline $\begin{array}{l}\text { BHV } \\
7\end{array}$ & ,283 & 1 & 87 & $\begin{array}{c}, 59 \\
6 \\
\end{array}$ & 6,359 & 1 & 87 & $\begin{array}{c}, 01 \\
4\end{array}$ & 1,194 & 1 & 87 & 278 \\
\hline $\begin{array}{l}\text { BHV } \\
8\end{array}$ & ,165 & 1 & 87 & $\begin{array}{c}68 \\
5\end{array}$ & ,236 & 1 & 87 & $\begin{array}{c}, 62 \\
8\end{array}$ & 6,296 & 1 & 87 & ,014 \\
\hline $\begin{array}{l}\text { BHV } \\
9\end{array}$ & ,140 & 1 & 87 & $\begin{array}{c}, 71 \\
0\end{array}$ & 199 & 1 & 87 & $\begin{array}{c}65 \\
7\end{array}$ & 135 & 1 & 87 & ,714 \\
\hline $\begin{array}{l}\text { BHV } \\
10 \\
\end{array}$ & 4,711 & 1 & 87 & $\begin{array}{c}, 03 \\
3\end{array}$ & 605 & 1 & 87 & $\begin{array}{c}43 \\
9\end{array}$ & ,528 & 1 & 87 & ,470 \\
\hline $\begin{array}{l}\text { BHV } \\
11\end{array}$ & ,806 & 1 & 87 & $\begin{array}{c}37 \\
2\end{array}$ & ,284 & 1 & 87 & $\begin{array}{c}, 59 \\
5\end{array}$ & 4,726 & 1 & 87 & ,032 \\
\hline $\begin{array}{l}\mathrm{BHV} \\
12 \\
\end{array}$ & ,048 & 1 & 87 & \begin{tabular}{|c|}
, 82 \\
8 \\
\end{tabular} & ,449 & 1 & 87 & $\begin{array}{c}, 50 \\
5 \\
\end{array}$ & ,461 & 1 & 87 & 499 \\
\hline $\begin{array}{l}\text { BHV } \\
13\end{array}$ & ,423 & 1 & 87 & $\begin{array}{c}, 51 \\
7\end{array}$ & 962 & 1 & 87 & $\begin{array}{c}32 \\
9\end{array}$ & 099 & 1 & 87 & ,753 \\
\hline $\begin{array}{l}\text { BHV } \\
14\end{array}$ & 1,103 & 1 & 87 & $\begin{array}{c}, 29 \\
7\end{array}$ & 2,610 & 1 & 87 & $\begin{array}{c}111 \\
0\end{array}$ & 360 & 1 & 87 & ,550 \\
\hline $\begin{array}{l}\text { BHV } \\
15 \\
\end{array}$ & , 010 & 1 & 87 & $\begin{array}{c}92 \\
0\end{array}$ & 698 & 1 & 87 & $\begin{array}{c}40 \\
6\end{array}$ & 141 & 1 & 87 & 709 \\
\hline $\begin{array}{l}\text { BHV } \\
16\end{array}$ & 3,003 & 1 & 87 & $\begin{array}{c}, 08 \\
7\end{array}$ & 4,860 & 1 & 87 & $\begin{array}{c}, 03 \\
0\end{array}$ & ,001 & 1 & 87 & ,975 \\
\hline $\begin{array}{l}\text { BHV } \\
17\end{array}$ & ,066 & 1 & 87 & $\begin{array}{c}79 \\
9\end{array}$ & 1,944 & 1 & 87 & $\begin{array}{c}16 \\
7\end{array}$ & 2,465 & 1 & 87 & 120, \\
\hline $\begin{array}{l}\text { BHV } \\
18 \\
\end{array}$ & 1,002 & 1 & 87 & $\begin{array}{c}32 \\
0\end{array}$ & 2,532 & 1 & 87 & $\begin{array}{c}111 \\
5\end{array}$ & 246 & 1 & 87 & 621, \\
\hline $\begin{array}{l}\text { BHV } \\
19\end{array}$ & ,015 & 1 & 87 & $\begin{array}{c}, 90 \\
3\end{array}$ & 4,647 & 1 & 87 & $\begin{array}{c}, 03 \\
4\end{array}$ & ,358 & 1 & 87 & ,551 \\
\hline
\end{tabular}

Source (SPSS)

Allal MOKEDDEM (2021), Journal of Internet Social Networking \& Virtual Communities,

DOI: $10.5171 / 2021.518860$ 
According to Table 21, the first part presents statistics that analyze the relationship between gender and the different ways of using social networks. Overall, the author accepts the hypothesis $\mathrm{H}_{0}$ that there is no relationship between gender and the user's attitude towards Facebook, with the exception of the two items: BHV4: "Form new relationships with a friend" and BHV15: "Feel concerned about Facebook when you are not logged", which have a different average around a threshold of $5 \%$. So, the probability of finding this value of $\mathrm{F}$, when the null hypothesis is true, is less than 0.05 , or less than $5 \%$.

The second part of the analysis process consists of testing the relationship between the occupation and the different ways of using social networks. The different behaviours of users on Facebook which vary by occupation are: BHV2: "Neglect household chores, work chores or university homework", BHV3: "Prefer the excitement of Facebook to spend time with your partner or best friends", BHV4: "Form new relationships with a friend", BHV5: "Other people in your life complain about your time on Facebook", BHV6: "Your school work or work suffer from the time you spend on Facebook" and BHV14: "Lose sleep due to a late Facebook connection".

The third part of the analysis process consists of testing the relationship between the location and the different ways of using social networks. It is found that in column (sig), the probability of finding this value of $\mathrm{F}$, when the null hypothesis is true, is greater than 0.05 , or more than $5 \%$. In this case, the author has enough evidence to accept the null hypothesis and say that it is likely that the behaviour of using social media is consistent from one location to another. 
Table 21: ANOVA

\begin{tabular}{|c|c|c|c|c|c|c|c|c|c|c|c|c|c|c|c|c|}
\hline \multicolumn{7}{|c|}{ Gender } & \multicolumn{5}{|c|}{ Occupation } & \multicolumn{5}{|c|}{ Location } \\
\hline & & $\begin{array}{l}\text { Sum } \\
\text { of } \\
\text { squa } \\
\text { res }\end{array}$ & $\begin{array}{l}d \\
f\end{array}$ & $\begin{array}{l}\text { Medi } \\
\text { um } \\
\text { squar } \\
\text { e }\end{array}$ & $\bar{F}$ & $\begin{array}{c}\mathrm{Si} \\
\mathrm{g}\end{array}$ & $\begin{array}{l}\text { Sum } \\
\text { of } \\
\text { squa } \\
\text { res }\end{array}$ & $\begin{array}{l}\mathrm{d} \\
\mathrm{f}\end{array}$ & $\begin{array}{l}\text { Medi } \\
\text { um } \\
\text { squar } \\
\text { e }\end{array}$ & $\bar{F}$ & $\begin{array}{l}\mathrm{Si} \\
\mathrm{g}\end{array}$ & $\begin{array}{l}\text { Sum } \\
\text { of } \\
\text { squar } \\
\text { es }\end{array}$ & $\overline{\mathrm{df}}$ & $\begin{array}{l}\text { Med } \\
\text { ium } \\
\text { squ } \\
\text { are }\end{array}$ & $\bar{F}$ & $\begin{array}{c}\mathrm{Si} \\
\mathrm{g}\end{array}$ \\
\hline \multirow{3}{*}{$\begin{array}{c}\text { BHV } \\
1\end{array}$} & Intergr & \multirow{3}{*}{$\begin{array}{c}103 \\
108 \\
302\end{array}$} & \multirow{3}{*}{$\begin{array}{l}1 \\
8 \\
7\end{array}$} & \multirow{3}{*}{$\begin{array}{l}103 \\
1,245\end{array}$} & \multirow{3}{*}{$\begin{array}{l}, 0 \\
82\end{array}$} & \multirow{3}{*}{$\begin{array}{l}, 7 \\
75\end{array}$} & \multirow{3}{*}{$\begin{array}{c}, 760 \\
107 \\
644\end{array}$} & \multirow{3}{*}{$\begin{array}{l}1 \\
8 \\
7\end{array}$} & \multirow{3}{*}{$\begin{array}{c}, 760 \\
1,237\end{array}$} & \multirow{3}{*}{$\begin{array}{l}, 6 \\
15\end{array}$} & \multirow{3}{*}{$\begin{array}{l}, 4 \\
35\end{array}$} & \multirow{3}{*}{$\begin{array}{c}, 070 \\
108,3 \\
34\end{array}$} & \multirow{3}{*}{$\begin{array}{c}1 \\
87\end{array}$} & 07 & \multirow{3}{*}{$\begin{array}{l}, 0 \\
56\end{array}$} & \multirow{3}{*}{$\begin{array}{l}\text { 8 } \\
13\end{array}$} \\
\hline & oups & & & & & & & & & & & & & 0 & & \\
\hline & $\begin{array}{l}\text { Intragr } \\
\text { oups }\end{array}$ & & & & & & & & & & & & & $\begin{array}{l}1,2 \\
45\end{array}$ & & \\
\hline \multirow{3}{*}{$\begin{array}{c}\text { BHV } \\
2\end{array}$} & Intergr & \multirow{3}{*}{$\begin{array}{c}, 763 \\
58,1 \\
13\end{array}$} & \multirow{3}{*}{$\begin{array}{l}1 \\
8 \\
7\end{array}$} & \multirow{3}{*}{$\begin{array}{l}763 \\
, 668\end{array}$} & \multirow{3}{*}{$\begin{array}{c}1 \\
14 \\
3\end{array}$} & & 4,08 & & & & & & & 49 & & \\
\hline & oups & & & & & ,2 & 5 & $\begin{array}{l}1 \\
8\end{array}$ & 4,085 & $\begin{array}{l}0, \\
48\end{array}$ & 0 & 58,37 & 1 & 9 & 7 & ,3 \\
\hline & $\begin{array}{l}\text { Intragr } \\
\text { oups }\end{array}$ & & & & & & $\begin{array}{c}54,7 \\
92\end{array}$ & 7 & & 6 & & 7 & & $\begin{array}{c}, 67 \\
1\end{array}$ & 44 & \\
\hline $\mathrm{BHV}$ & Intergr & & 1 & & & & 8,85 & & & & & & & 1,0 & & \\
\hline 3 & oups & ' & 8 & ,285 & ,2 & 6 & 2 & $\begin{array}{l}1 \\
8\end{array}$ & 8,852 & $\begin{array}{l}0, \\
85\end{array}$ & 0 & $\begin{array}{l}1,048 \\
1200\end{array}$ & 1 & 48 & ,7 & ,3 \\
\hline & $\begin{array}{l}\text { Intragr } \\
\text { oups }\end{array}$ & $\begin{array}{l}120 \\
839\end{array}$ & 7 & 1,389 & 05 & 52 & $\begin{array}{l}112, \\
272\end{array}$ & $\begin{array}{l}8 \\
7\end{array}$ & 1,290 & $\begin{array}{c}85 \\
9\end{array}$ & 10 & $\begin{array}{l}120,0 \\
75\end{array}$ & 87 & $\begin{array}{l}1,3 \\
80\end{array}$ & 60 & 86 \\
\hline BHV & Intergr & 2,91 & 1 & & & & 1,92 & & & & & & & ,01 & & \\
\hline 4 & oups & 0 & 8 & 2,910 & 10 & , 0 & 5 & $\begin{array}{l}1 \\
8\end{array}$ & 1,925 & $\begin{array}{l}4, \\
57\end{array}$ & 0 & , 3854 & 1 & 8 & ,0 & ,9 \\
\hline & $\begin{array}{l}\text { Intragr } \\
\text { oups }\end{array}$ & $\begin{array}{c}35,6 \\
51\end{array}$ & 7 & ,410 & 2 & 09 & $\begin{array}{c}36,6 \\
36\end{array}$ & $\begin{array}{l}8 \\
7\end{array}$ & ,421 & 2 & 35 & $\begin{array}{c}30,54 \\
4\end{array}$ & 87 & $\begin{array}{c}, 44 \\
3\end{array}$ & 41 & 10 \\
\hline $\mathrm{BHV}$ & Intergr & & 1 & & & & 5,38 & & & & & & & ,01 & & \\
\hline 5 & oups & $\begin{array}{l}126 \\
979\end{array}$ & 8 & , 126 & 1 & ,7 & 8 & $\begin{array}{l}1 \\
8\end{array}$ & 5,388 & $\begin{array}{l}5, \\
05\end{array}$ & 0 & $\begin{array}{l}015 \\
9807\end{array}$ & 1 & 5 & 0 & 8 \\
\hline & $\begin{array}{l}\text { Intragr } \\
\text { oups }\end{array}$ & 64 & 7 & 1,126 & 11 & 39 & $\begin{array}{c}92,7 \\
02\end{array}$ & $\begin{array}{l}8 \\
7\end{array}$ & 1,066 & 6 & 27 & $\begin{array}{c}90,07 \\
5\end{array}$ & 87 & $\begin{array}{l}1,1 \\
27\end{array}$ & 13 & 41 \\
\hline BHV & Intergr & & 1 & & & & 5,97 & 1 & & & & & & ,69 & & \\
\hline 6 & oups & , 445 & 8 & ,445 & ,5 &, 4 & 5 & $\begin{array}{l}1 \\
8\end{array}$ & 5,975 & 26 & 0 & $\begin{array}{l}690 \\
7681\end{array}$ & 1 & 0 & ,7 & 3 \\
\hline & $\begin{array}{l}\text { Intragr } \\
\text { oups }\end{array}$ & 60 & 7 & 886 & 03 & 80 & $\begin{array}{c}71,5 \\
31 \\
\end{array}$ & $\begin{array}{l}0 \\
7\end{array}$ & ,822 & 7 & 08 & $\begin{array}{l}0,01 \\
5\end{array}$ & 87 & $\begin{array}{c}, 88 \\
3\end{array}$ & 82 & 79 \\
\hline BHV & Intergr & & 1 & & & & 3,92 & & & & & & & ,03 & & \\
\hline 7 & oups & , 119 & 8 & ,096 & , & ,7 & 1 & $\begin{array}{l}1 \\
8\end{array}$ & 3,921 & $\begin{array}{l}2, \\
95\end{array}$ & 0 & 1194 & 1 & 7 & , & 8 \\
\hline & $\begin{array}{l}\text { Intragr } \\
\text { oups }\end{array}$ & $\begin{array}{l}119, \\
342\end{array}$ & 7 & 1,372 & 70 & 91 & $\begin{array}{l}115, \\
518\end{array}$ & $\begin{array}{l}8 \\
7\end{array}$ & 1,328 & $\begin{array}{l}95 \\
3\end{array}$ & 89 & $\begin{array}{c}119,4 \\
01\end{array}$ & 87 & $\begin{array}{l}1,3 \\
72\end{array}$ & 27 & 70 \\
\hline BHV & Intergr & & 1 & & & & & 1 & & & & & & ,23 & & \\
\hline 8 & oups & , 015 & 8 & ,015 & 0 & 8 & ,092 & $\begin{array}{l}1 \\
8\end{array}$ & ,092 & 1 & ,7 & $\begin{array}{l}, 234 \\
5520\end{array}$ & 1 & 4 & ,3 &, 5 \\
\hline & $\begin{array}{l}\text { Intragr } \\
\text { oups }\end{array}$ & $\begin{array}{c}33,4 \\
23\end{array}$ & 7 & 637 & 23 & 80 & $\begin{array}{c}53,3 \\
47\end{array}$ & $\begin{array}{l}0 \\
7\end{array}$ & 636 & 44 & 05 & $\begin{array}{c}53,20 \\
4\end{array}$ & 87 & $\begin{array}{c}, 63 \\
5\end{array}$ & 69 & 45 \\
\hline BHV & Intergr & 213 & 1 & & & & & & & & & & & ,13 & & \\
\hline 9 & oups & $\begin{array}{l}213 \\
65.6\end{array}$ & 8 & ,213 &, 2 & ,5 & $\begin{array}{l}610 \\
65.8\end{array}$ & $\begin{array}{l}1 \\
8\end{array}$ & ,016 & 0 & ,8 & 65.74 & 1 & 9 & , 1 & 6 \\
\hline & $\begin{array}{l}\text { Intragr } \\
\text { oups }\end{array}$ & $\begin{array}{c}65,6 \\
75\end{array}$ & 7 & ,755 & 82 & 97 & $\begin{array}{c}65,8 \\
71\end{array}$ & $\begin{array}{l}8 \\
7\end{array}$ & 757 & 22 & 83 & $\begin{array}{c}65, / 4 \\
9\end{array}$ & 87 & $\begin{array}{c}, 75 \\
6\end{array}$ & 84 & 69 \\
\hline $\mathrm{BHV}$ & Intergr & & 1 & & & & & & & & & & & ,84 & & \\
\hline 10 & oups & 929 & -8 & -, 017 & & ,9 & 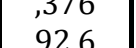 & $\begin{array}{l}1 \\
8\end{array}$ & ,376 & ,3 &, 5 & $\begin{array}{l}\text {,845 } \\
9214\end{array}$ & 1 & 5 & ,7 & , 3 \\
\hline & $\begin{array}{l}\text { Intragr } \\
\text { oups }\end{array}$ & $\begin{array}{c}92,9 \\
\text { Allabla } \\
\text { DoI: } 10\end{array}$ & $\begin{array}{l}\mathrm{KL}^{7} \mathrm{DI} \\
171\end{array}$ & $\begin{array}{l}\mathrm{EH} 96282 \\
202151\end{array}$ & 1), $150 \mathrm{ur}$ & nal of & $\begin{array}{c}92,6 \\
\text { nterßet S }\end{array}$ & $\begin{array}{c}8 \\
\text { octăal }\end{array}$ & vetw85kir & $\mathrm{g} 3 \mathrm{Vi}$ & tưâ c & $\begin{array}{c}92,14 \\
\text { pmminiti }\end{array}$ & $s^{87}$ & $\begin{array}{l}1,0 \\
59 \\
\end{array}$ & 98 & 74 \\
\hline BHV & Intergr & 669 & 1 & & 6 &, 4 & ,452 & 1 & &, 4 &, 5 & 1,055 & & 1,0 & 1 & ,3 \\
\hline & $\begin{array}{l}\text { Intragr } \\
\text { oups }\end{array}$ & $\begin{array}{c}88,2 \\
30\end{array}$ & 7 & 1,014 & 59 & 19 & $\begin{array}{c}88,4 \\
47\end{array}$ & $\begin{array}{l}8 \\
7\end{array}$ & 1,017 & 44 & 07 & $\begin{array}{c}87,84 \\
4\end{array}$ & $\begin{array}{c}1 \\
87\end{array}$ & $\begin{array}{l}50 \\
1,0 \\
10\end{array}$ & 04 & 10 \\
\hline $\mathrm{BHV}$ & Intergr & ,145 & 1 &, 145 & ,1 & ,7 & ,330 & 1 & ,330 & 2 & 6 & ,006 & 1 & 006 & , & 9 \\
\hline
\end{tabular}




\begin{tabular}{|c|c|c|c|c|c|c|c|c|c|c|c|c|c|c|c|c|}
\hline \multirow[t]{2}{*}{12} & oups & \multirow{2}{*}{$\begin{array}{l}123, \\
136\end{array}$} & \multirow{2}{*}{$\begin{array}{l}8 \\
7\end{array}$} & \multirow[t]{2}{*}{1,415} & \multirow[t]{2}{*}{03} & \multirow[t]{2}{*}{50} & \multirow{2}{*}{$\begin{array}{l}122 \\
951\end{array}$} & \multirow{2}{*}{$\begin{array}{l}8 \\
7\end{array}$} & \multirow[t]{2}{*}{1,413} & \multirow[t]{2}{*}{34} & \multirow[t]{2}{*}{30} & \multirow{2}{*}{$\begin{array}{c}123,2 \\
75\end{array}$} & \multirow[t]{2}{*}{87} & \multirow{2}{*}{$\begin{array}{l}1,4 \\
17\end{array}$} & \multirow[t]{2}{*}{04} & \multirow[t]{2}{*}{50} \\
\hline & $\begin{array}{l}\text { Intragr } \\
\text { oups }\end{array}$ & & & & & & & & & & & & & & & \\
\hline \multirow{3}{*}{$\begin{array}{c}\text { BHV } \\
13\end{array}$} & Intergr & \multirow{3}{*}{$\begin{array}{c}, 342 \\
65,1 \\
86\end{array}$} & \multirow{3}{*}{$\begin{array}{l}1 \\
8 \\
7\end{array}$} & \multirow{3}{*}{$\begin{array}{l}\text {,342 } \\
, 749\end{array}$} & \multirow{3}{*}{$\begin{array}{l}, 4 \\
56\end{array}$} & \multirow{3}{*}{$\begin{array}{l}, 5 \\
01\end{array}$} & \multirow{3}{*}{$\begin{array}{c}, 016 \\
65,5 \\
12\end{array}$} & \multirow{3}{*}{$\begin{array}{l}1 \\
8 \\
7\end{array}$} & \multirow{3}{*}{$\begin{array}{l}, 016 \\
, 753\end{array}$} & \multirow{3}{*}{$\begin{array}{l}, 0 \\
21\end{array}$} & \multirow{3}{*}{$\begin{array}{l}, 8 \\
85\end{array}$} & \multirow{3}{*}{$\begin{array}{c}, 004 \\
65,52 \\
4\end{array}$} & \multirow{3}{*}{$\begin{array}{c}1 \\
87\end{array}$} & ,00 & & \\
\hline & oups & & & & & & & & & & & & & 4 & 0 & ,9 \\
\hline & $\begin{array}{l}\text { Intragr } \\
\text { oups }\end{array}$ & & & & & & & & & & & & & $\begin{array}{c}, 75 \\
3\end{array}$ & 06 & 40 \\
\hline BHV & Intergr & 3,79 & 1 & & & & 9,39 & & & & & & & ,00 & & \\
\hline 14 & oups & 7 & 8 & 3,797 & $\begin{array}{c}3, \\
71\end{array}$ &, 0 & 4 & $\begin{array}{l}1 \\
8\end{array}$ & 9,394 & $\begin{array}{l}9, \\
80\end{array}$ & 0 & $\begin{array}{l}, 004 \\
9271\end{array}$ & 1 & 4 & 0 & ,9 \\
\hline & $\begin{array}{l}\text { Intragr } \\
\text { oups }\end{array}$ & $\begin{array}{c}88,9 \\
22\end{array}$ & & 1,022 & 5 & 57 & $\begin{array}{c}83,3 \\
25\end{array}$ & 7 & ,958 & 8 & 02 & 5 & 87 & $\begin{array}{l}1,0 \\
66\end{array}$ & 04 & 52 \\
\hline $\mathrm{BHV}$ & Intergr & 5,11 & 1 & & & & 1,85 & 1 & & & & & & ,02 & & \\
\hline 15 & oups & 5 & 8 & 5,115 & $\begin{array}{r}0 \\
54\end{array}$ & ,0 & 5 & $\begin{array}{l}1 \\
8\end{array}$ & 1,855 & $\begin{array}{r}2, \\
26\end{array}$ & 1 & 73.10 & 1 & 0 & , & 8 \\
\hline & $\begin{array}{l}\text { Intragr } \\
\text { oups }\end{array}$ & $\begin{array}{r}68,0 \\
08\end{array}$ & 7 & ,782 & $\begin{array}{r}34 \\
4\end{array}$ & 12 & $\begin{array}{c}71,2 \\
69\end{array}$ & $\begin{array}{l}0 \\
7\end{array}$ & ,819 & $\begin{array}{r}20 \\
4\end{array}$ & 36 & 4 & 87 & $\begin{array}{r}, 84 \\
0\end{array}$ & 24 & 78 \\
\hline BHV & Intergr & & 1 & & & & 3,39 & & & & & & & ,09 & & \\
\hline 16 & oups & $\begin{array}{l}436 \\
110 .\end{array}$ & 8 & ,436 & ,3 & ,5 & 1 & $\begin{array}{l}1 \\
8\end{array}$ & 3,391 & $\begin{array}{r}2, \\
75\end{array}$ & ,1 & $\begin{array}{r}, 091 \\
110,4\end{array}$ & 1 & 1 & , 0 & 7 \\
\hline & $\begin{array}{l}\text { Intragr } \\
\text { oups }\end{array}$ & 059 & 7 & 1,265 & 44 & 59 & $\begin{array}{l}107 \\
103 \\
\end{array}$ & 7 & 1,231 & 5 & 01 & 04 & 87 & $\begin{array}{r}1,2 \\
69 \\
\end{array}$ & 71 & 90 \\
\hline BHV & Intergr & & 1 & & & & & & & & & & & 1,5 & & \\
\hline 17 & oups & $\begin{array}{l}300 \\
109 .\end{array}$ & 8 & ,306 & , 2 & 6 & 108 & $\begin{array}{l}1 \\
8\end{array}$ & ,576 &, 4 & ,4 & $\begin{array}{l}1,594 \\
1078\end{array}$ & 1 & 94 & 1 , & , \\
\hline & $\begin{array}{l}\text { Intragr } \\
\text { oups }\end{array}$ & 132 & 7 & 1,254 & 44 & 23 & $\begin{array}{l}108, \\
862\end{array}$ & $\begin{array}{l}8 \\
7\end{array}$ & 1,251 & 61 & 99 & $\begin{array}{r}107,8 \\
44\end{array}$ & 87 & $\begin{array}{r}1,2 \\
40 \\
\end{array}$ & 28 & 60 \\
\hline $\mathrm{BHV}$ & Intergr & & 1 & & & & 2,89 & & & & & & & ,12 & & \\
\hline 18 & oups & 85,4 & $\begin{array}{l}8 \\
7\end{array}$ & ,078 & 0 & ,7 & 2 & $\begin{array}{l}1 \\
8\end{array}$ & 2,892 & $\begin{array}{r}3, \\
04\end{array}$ & ,0 & 85,40 & 1 & 7 & ,1 & ,7 \\
\hline & $\begin{array}{l}\text { Intragr } \\
\text { oups }\end{array}$ & 50 & 7 & , 982 & 79 & 79 & $\begin{array}{c}82,6 \\
36 \\
\end{array}$ & 7 & ,950 & 4 & 85 & 1 & 87 & $\begin{array}{r}, 98 \\
2 \\
\end{array}$ & 30 & 20 \\
\hline BHV & Intergr & 2,00 & 1 & & & & 1,67 & & & & & & & ,15 & & \\
\hline 19 & oups & 8 & 8 & 2,008 & 51 & ,1 & 8 & $\begin{array}{l}1 \\
8\end{array}$ & 1,678 & 09 & ,1 & 71,28 & 1 & 2 & ,1 & 6 \\
\hline & $\begin{array}{l}\text { Intragr } \\
\text { oups }\end{array}$ & $\begin{array}{c}69,4 \\
30\end{array}$ & 7 & ,798 & 7 & 16 & $\begin{array}{c}69,7 \\
61\end{array}$ & 7 & ,802 & 2 & 52 & 7 & 87 & $\begin{array}{c}, 81 \\
9\end{array}$ & 85 & 68 \\
\hline
\end{tabular}

Source (SPSS)

\section{Effect of user support on attitude towards Facebook:}

From Table 22, the author retains heterogeneity around the variance for the following items: BHV1, BH7, BH16, BH17 and $\mathrm{BH} 18$, where the significance level is less than $5 \%$. The rest of the items show homogeneity around the variance. This leads the author to accept the null hypothesis. 
Table 22: Homogeneity of variance test

\begin{tabular}{|c|c|c|c|c|}
\hline & Levene statistics & df1 & df2 & Sig. \\
\hline BHV1 & 3,513 & 3 & 85 & ,019 \\
\hline BHV2 & ,501 & 3 & 85 & ,683 \\
\hline BHV3 & 1,168 & 3 & 85 & ,327 \\
\hline BHV4 & 1,877 & 3 & 85 & ,140 \\
\hline BHV5 & 1,131 & 3 & 85 & ,341 \\
\hline BHV6 & ,542 & 3 & 85 & 655 \\
\hline BHV7 & 4,055 & 3 & 85 & 010 \\
\hline BHV8 & 1,571 & 3 & 85 & ,202 \\
\hline BHV9 & 2,433 & 3 & 85 & ,070 \\
\hline BHV10 & 2,447 & 3 & 85 & ,069 \\
\hline BHV11 & 1,537 & 3 & 85 & ,211 \\
\hline BHV12 & ,790 & 3 & 85 & ,503 \\
\hline BHV13 & 846 & 3 & 85 & ,473 \\
\hline BHV14 & 2,397 & 3 & 85 & ,074 \\
\hline BHV15 & ,545 & 3 & 85 & ,653 \\
\hline BHV16 & 3,776 & 3 & 85 & ,013 \\
\hline BHV17 & 4,766 & 3 & 85 & ,004 \\
\hline BHV18 & 3,012 & 3 & 85 & ,035 \\
\hline BHV19 & ,469 & 3 & 85 & 705 \\
\hline
\end{tabular}

Source: (SPSS)

Table 23 shows that the behaviour of the user is the same regardless of the activity medium used when logging in. More than $85.5 \%$ of the Algerian students use Smartphone as a means of interaction with the blue environment, while $10.1 \%$ are strongly linked to the machine (Laptop). Finally, only $4.4 \%$ use the desktop and the I-pad.

Allal MOKEDDEM (2021), Journal of Internet Social Networking \& Virtual Communities, DOI: $10.5171 / 2021.518860$ 
Table 23: ANOVA

\begin{tabular}{|c|c|c|c|c|c|c|}
\hline & & $\begin{array}{c}\text { Sum of } \\
\text { squares }\end{array}$ & $\mathrm{df}$ & $\begin{array}{l}\text { Medium } \\
\text { square }\end{array}$ & $\bar{F}$ & Sig \\
\hline \multirow[t]{3}{*}{ BHV1 } & $\begin{array}{c}\text { Intergrou } \\
\text { ps }\end{array}$ & 2,112 & 3 & ,704 & \multirow{3}{*}{$\begin{array}{c}, 56 \\
3\end{array}$} & \multirow{3}{*}{ 641 } \\
\hline & $\begin{array}{c}\text { Intragrou } \\
\text { ps }\end{array}$ & 106,292 & 85 & \multirow[t]{2}{*}{1,250} & & \\
\hline & Total & 108,404 & 88 & & & \\
\hline \multirow[t]{3}{*}{ BHV2 } & $\begin{array}{c}\text { Intergrou } \\
\text { ps }\end{array}$ & 2,216 & 3 & ,739 & \multirow{3}{*}{$\begin{array}{l}1,1 \\
08\end{array}$} & \multirow{3}{*}{,351 } \\
\hline & $\begin{array}{c}\text { Intragrou } \\
\text { ps }\end{array}$ & 56,661 & 85 & \multirow[t]{2}{*}{,667 } & & \\
\hline & Total & 58,876 & 88 & & & \\
\hline \multirow[t]{3}{*}{ BHV3 } & $\begin{array}{c}\text { Intergrou } \\
\text { ps }\end{array}$ & 6,926 & 3 & 2,309 & \multirow{3}{*}{$\begin{array}{l}1,7 \\
18\end{array}$} & \multirow{3}{*}{ 169 } \\
\hline & $\begin{array}{c}\text { Intragrou } \\
\text { ps }\end{array}$ & 114,197 & 85 & \multirow[t]{2}{*}{1,343} & & \\
\hline & Total & 121,124 & 88 & & & \\
\hline \multirow[t]{3}{*}{ BHV4 } & $\begin{array}{c}\text { Intergrou } \\
\text { ps }\end{array}$ & ,256 & 3 & ,085 & \multirow{3}{*}{$\begin{array}{c}, 19 \\
0\end{array}$} & \multirow{3}{*}{ 903 } \\
\hline & $\begin{array}{c}\text { Intragrou } \\
\text { ps }\end{array}$ & 38,306 & 85 & \multirow[t]{2}{*}{,451 } & & \\
\hline & Total & 38,562 & 88 & & & \\
\hline \multirow[t]{3}{*}{ BHV5 } & $\begin{array}{c}\text { Intergrou } \\
\text { ps }\end{array}$ & 1,986 & 3 & 662 & \multirow{3}{*}{$\begin{array}{c}, 58 \\
6\end{array}$} & \multirow{3}{*}{ 626 } \\
\hline & $\begin{array}{c}\text { Intragrou } \\
\text { ps }\end{array}$ & 96,104 & 85 & \multirow[t]{2}{*}{1,131} & & \\
\hline & Total & 98,090 & 88 & & & \\
\hline \multirow[t]{3}{*}{ BHV6 } & $\begin{array}{c}\text { Intergrou } \\
\text { ps }\end{array}$ & 769 & 3 & 256 & \multirow{3}{*}{$\begin{array}{c}, 28 \\
4\end{array}$} & \multirow{3}{*}{ 837 } \\
\hline & $\begin{array}{c}\text { Intragrou } \\
\text { ps }\end{array}$ & 76,737 & 85 & \multirow[t]{2}{*}{,903 } & & \\
\hline & Total & 77,506 & 88 & & & \\
\hline \multirow[t]{3}{*}{ BHV7 } & $\begin{array}{c}\text { Intergrou } \\
\text { ps }\end{array}$ & 4,128 & 3 & 1,376 & \multirow{3}{*}{$\begin{array}{l}1,0 \\
14\end{array}$} & \multirow{3}{*}{ 390 } \\
\hline & $\begin{array}{c}\text { Intragrou } \\
\text { ps }\end{array}$ & 115,310 & 85 & \multirow[t]{2}{*}{1,357} & & \\
\hline & Total & 119,438 & 88 & & & \\
\hline \multirow[t]{3}{*}{ BHV8 } & $\begin{array}{c}\text { Intergrou } \\
\text { ps }\end{array}$ & 780 & 3 & ,260 & \multirow{3}{*}{$\begin{array}{c}, 40 \\
4\end{array}$} & \multirow{3}{*}{ 750 } \\
\hline & $\begin{array}{c}\text { Intragrou } \\
\text { ps }\end{array}$ & 54,658 & 85 & 643 & & \\
\hline & Total & 55,438 & 88 & & & \\
\hline BHV9 & $\begin{array}{c}\text { Intergrou } \\
\text { ps } \\
\end{array}$ & 2,468 & 3 & 823 & 1,1 & 52 \\
\hline & $\begin{array}{c}\text { Intragrou } \\
\text { ps }\end{array}$ & 63,420 & 85 & ,746 & 03 & ,353, \\
\hline & Total & 65,888 & 88 & & & \\
\hline BHV10 & Intergrou & 5,462 & 3 & 1,821 & 1,7 & 159 \\
\hline
\end{tabular}

Allal MOKEDDEM (2021), Journal of Internet Social Networking \& Virtual Communities, DOI : $10.5171 / 2021.518860$ 


\begin{tabular}{|c|c|c|c|c|c|c|}
\hline & ps & & & \multirow{3}{*}{1,030} & \multirow[t]{3}{*}{68} & \\
\hline & $\begin{array}{c}\text { Intragrou } \\
\text { ps }\end{array}$ & 87,526 & 85 & & & \\
\hline & Total & 92,989 & 88 & & & \\
\hline \multirow[t]{3}{*}{ BHV11 } & $\begin{array}{c}\text { Intergrou } \\
\text { ps }\end{array}$ & 2,873 & 3 & ,958 & \multirow{3}{*}{$\begin{array}{c}, 94 \\
6\end{array}$} & \multirow{3}{*}{,422 } \\
\hline & $\begin{array}{c}\text { Intragrou } \\
\text { ps }\end{array}$ & 86,026 & 85 & \multirow[t]{2}{*}{1,012} & & \\
\hline & Total & 88,899 & 88 & & & \\
\hline \multirow[t]{3}{*}{ BHV12 } & $\begin{array}{c}\text { Intergrou } \\
\text { ps }\end{array}$ & ,847 & 3 & ,282 & \multirow{3}{*}{$\begin{array}{c}19 \\
6\end{array}$} & \multirow{3}{*}{,899 } \\
\hline & $\begin{array}{c}\text { Intragrou } \\
\text { ps }\end{array}$ & 122,434 & 85 & \multirow[t]{2}{*}{1,440} & & \\
\hline & Total & 123,281 & 88 & & & \\
\hline \multirow[t]{3}{*}{ BHV13 } & $\begin{array}{c}\text { Intergrou } \\
\text { ps }\end{array}$ & 1,600 & 3 & ,533 & \multirow{3}{*}{$\begin{array}{c}, 70 \\
9\end{array}$} & \multirow{3}{*}{,549 } \\
\hline & $\begin{array}{c}\text { Intragrou } \\
\text { ps } \\
\end{array}$ & 63,928 & 85 & \multirow[t]{2}{*}{,752 } & & \\
\hline & Total & 65,528 & 88 & & & \\
\hline \multirow[t]{3}{*}{ BHV14 } & $\begin{array}{c}\text { Intergrou } \\
\text { ps }\end{array}$ & 2,497 & 3 & ,832 & \multirow{3}{*}{$\begin{array}{c}, 78 \\
4\end{array}$} & \multirow{3}{*}{,506 } \\
\hline & $\begin{array}{c}\text { Intragrou } \\
\text { ps }\end{array}$ & 90,222 & 85 & \multirow[t]{2}{*}{1,061} & & \\
\hline & Total & 92,719 & 88 & & & \\
\hline \multirow[t]{3}{*}{ BHV15 } & $\begin{array}{c}\text { Intergrou } \\
\text { ps }\end{array}$ & ,458 & 3 & ,153 & \multirow{3}{*}{$\begin{array}{c}, 17 \\
9\end{array}$} & \multirow{3}{*}{,911 } \\
\hline & $\begin{array}{c}\text { Intragrou } \\
\text { ps } \\
\end{array}$ & 72,665 & 85 & \multirow[t]{2}{*}{,855 } & & \\
\hline & Total & 73,124 & 88 & & & \\
\hline \multirow[t]{3}{*}{ BHV16 } & $\begin{array}{c}\text { Intergrou } \\
\text { ps }\end{array}$ & 1,968 & 3 & ,656 & \multirow{3}{*}{$\begin{array}{c}, 51 \\
4\end{array}$} & \multirow{3}{*}{ 674 } \\
\hline & $\begin{array}{c}\text { Intragrou } \\
\text { ps } \\
\end{array}$ & 108,526 & 85 & \multirow[t]{2}{*}{1,277} & & \\
\hline & Total & 110,494 & 88 & & & \\
\hline \multirow[t]{3}{*}{ BHV17 } & $\begin{array}{c}\text { Intergrou } \\
\text { ps } \\
\end{array}$ & 7,523 & 3 & 2,508 & \multirow{3}{*}{$\begin{array}{l}2,0 \\
91\end{array}$} & \multirow{3}{*}{ 107 } \\
\hline & $\begin{array}{c}\text { Intragrou } \\
\text { ps } \\
\end{array}$ & 101,915 & 85 & \multirow[t]{2}{*}{1,199} & & \\
\hline & Total & 109,438 & 88 & & & \\
\hline \multirow[t]{3}{*}{ BHV18 } & $\begin{array}{c}\text { Intergrou } \\
\text { ps } \\
\end{array}$ & 2,674 & 3 & ,891 & ,91 & \\
\hline & $\begin{array}{c}\text { Intragrou } \\
\text { ps } \\
\end{array}$ & 82,854 & 85 & ,975 & 5 & 438, \\
\hline & Total & 85,528 & 88 & & & \\
\hline BHV19 & $\begin{array}{c}\text { Intergrou } \\
\text { ps }\end{array}$ & ,412 & 3 & ,137 & & \\
\hline & $\begin{array}{c}\text { Intragrou } \\
\text { ps } \\
\end{array}$ & 71,026 & 85 & ,836 & $\begin{array}{c}, 16 \\
4\end{array}$ & 920 \\
\hline & Total & 71,438 & 88 & & & \\
\hline
\end{tabular}

Source: (SPSS)

Allal MOKEDDEM (2021), Journal of Internet Social Networking \& Virtual Communities, DOI: $10.5171 / 2021.518860$ 
Effect of user cost on attitude towards Facebook:

From Table 24, the author retains homogeneity around the variance on all the items of the study. The test of Levene made the exception around the variance on some elements of the study. The variance is strongly different between the following items: BHV4, BHV8, BHV9, BHV10, BHV16 and BHV19.

Table 24: Homogeneity of variance test

\begin{tabular}{|c|c|c|c|c|}
\hline & $\begin{array}{l}\text { Levene } \\
\text { statistics }\end{array}$ & $\begin{array}{c}\mathrm{ddf} \\
1\end{array}$ & ddf2 & Sig. \\
\hline $\begin{array}{l}\text { BHV } \\
1\end{array}$ & 2,110 & 2 & 86 & ,127 \\
\hline $\begin{array}{l}\text { BHV } \\
2\end{array}$ & 131 & 2 & 86 & 877 \\
\hline $\begin{array}{l}\text { BHV } \\
3\end{array}$ & 120 & 2 & 86 & 887 \\
\hline $\begin{array}{l}\text { BHV } \\
4\end{array}$ & 9,115 & 2 & 86 & ,000 \\
\hline $\begin{array}{l}\text { BHV } \\
5\end{array}$ & ,903 & 2 & 86 & ,409 \\
\hline $\begin{array}{l}\text { BHV } \\
6\end{array}$ & 1,108 & 2 & 86 & ,335 \\
\hline $\begin{array}{l}\text { BHV } \\
7 \\
\end{array}$ & 1,840 & 2 & 86 & ,165 \\
\hline $\begin{array}{l}\text { BHV } \\
8\end{array}$ & 4,100 & 2 & 86 & ,020 \\
\hline $\begin{array}{l}\text { BHV } \\
9\end{array}$ & 6,996 & 2 & 86 & ,002 \\
\hline $\begin{array}{l}\text { BHV } \\
10\end{array}$ & 4,531 & 2 & 86 & ,013 \\
\hline $\begin{array}{l}\text { BHV } \\
11 \\
\end{array}$ & ,045 & 2 & 86 & ,956 \\
\hline $\begin{array}{l}\text { BHV } \\
12\end{array}$ & 1,619 & 2 & 86 & ,204 \\
\hline $\begin{array}{l}\text { BHV } \\
13 \\
\end{array}$ & 630 & 2 & 86 & ,535 \\
\hline $\begin{array}{l}\text { BHV } \\
14 \\
\end{array}$ & 271 & 2 & 86 & ,763 \\
\hline $\begin{array}{l}\text { BHV } \\
15 \\
\end{array}$ & 1,018 & 2 & 86 & ,365 \\
\hline $\begin{array}{l}\text { BHV } \\
16 \\
\end{array}$ & 6,516 & 2 & 86 & ,002 \\
\hline $\begin{array}{l}\text { BHV } \\
17 \\
\end{array}$ & 1,118 & 2 & 86 & ,332 \\
\hline $\begin{array}{l}\text { BHV } \\
18 \\
\end{array}$ & ,271 & 2 & 86 & ,763 \\
\hline $\begin{array}{l}\text { BHV } \\
19 \\
\end{array}$ & 5,674 & 2 & 86 & ,005 \\
\hline
\end{tabular}

Source: (SPSS)

Allal MOKEDDEM (2021), Journal of Internet Social Networking \& Virtual Communities, DOI : $10.5171 / 2021.518860$ 
Table 25 shows that the financial factor has no effect on the behaviour and attitude of the user when using Facebook. In this context, the user's behaviour on Facebook will be the same regardless of the cost of use estimated by the user. In the case under study, $70.8 \%$ of Facebook users see that the cost of use is not expensive at all, $24.7 \%$ see that the cost of using Facebook is moderately expensive, and $4.5 \%$ see that the cost of use is very expensive compared to their standard of living. In conclusion, the author accepts the null hypothesis which describes the equality of variances.

Table 25: ANOVA

\begin{tabular}{|c|c|c|c|c|c|c|}
\hline & & $\begin{array}{c}\text { Sum of } \\
\text { squares }\end{array}$ & df & $\begin{array}{c}\text { Medium } \\
\text { square }\end{array}$ & $\mathbf{F}$ & Sig. \\
\hline \multirow[t]{3}{*}{ BHV1 } & $\begin{array}{c}\text { Intergro } \\
\text { upes }\end{array}$ & ,945 & 2 &, 473 & \multirow{3}{*}{$\begin{array}{c}, 37 \\
8\end{array}$} & \multirow[t]{3}{*}{,686 } \\
\hline & $\begin{array}{c}\text { Intragro } \\
\text { upes }\end{array}$ & 107,459 & 86 & \multirow[t]{2}{*}{1,250} & & \\
\hline & Total & 108,404 & 88 & & & \\
\hline \multirow[t]{3}{*}{ BHV2 } & $\begin{array}{c}\text { Intergro } \\
\text { upes }\end{array}$ & ,700 & 2 & ,350 & \multirow{3}{*}{$\begin{array}{c}51 \\
7\end{array}$} & \multirow[t]{3}{*}{,598 } \\
\hline & $\begin{array}{c}\text { Intragro } \\
\text { upes }\end{array}$ & 58,177 & 86 & \multirow[t]{2}{*}{,676 } & & \\
\hline & Total & 58,876 & 88 & & & \\
\hline \multirow[t]{3}{*}{ BHV3 } & $\begin{array}{c}\text { Intergro } \\
\text { upes }\end{array}$ & 2,046 & 2 & 1,023 & \multirow{3}{*}{$\begin{array}{c}73 \\
9\end{array}$} & \multirow[t]{3}{*}{,481 } \\
\hline & $\begin{array}{c}\text { Intragro } \\
\text { upes }\end{array}$ & 119,078 & 86 & 1,385 & & \\
\hline & Total & 121,124 & 88 & & & \\
\hline \multirow[t]{3}{*}{ BHV4 } & $\begin{array}{c}\text { Intergro } \\
\text { upes }\end{array}$ & 1,091 & 2 & ,546 & \multirow{3}{*}{$\begin{array}{l}1,2 \\
52\end{array}$} & \multirow[t]{3}{*}{,291 } \\
\hline & $\begin{array}{c}\text { Intragro } \\
\text { upes }\end{array}$ & 37,471 & 86 & ,436 & & \\
\hline & Total & 38,562 & 88 & & & \\
\hline \multirow[t]{3}{*}{ BHV5 } & $\begin{array}{c}\text { Intergro } \\
\text { upes }\end{array}$ & 2,131 & 2 & 1,065 & \multirow[t]{3}{*}{$\begin{array}{c}, 95 \\
5\end{array}$} & \multirow[t]{3}{*}{,389 } \\
\hline & $\begin{array}{c}\text { Intragro } \\
\text { upes }\end{array}$ & 95,959 & 86 & 1,116 & & \\
\hline & Total & 98,090 & 88 & & & \\
\hline \multirow[t]{3}{*}{ BHV6 } & $\begin{array}{c}\text { Intergro } \\
\text { upes }\end{array}$ & 2,281 & 2 & 1,141 & \multirow{3}{*}{$\begin{array}{l}1,3 \\
04\end{array}$} & \multirow[t]{3}{*}{,277 } \\
\hline & $\begin{array}{c}\text { Intragro } \\
\text { upes }\end{array}$ & 75,224 & 86 & ,875 & & \\
\hline & Total & 77,506 & 88 & & & \\
\hline \multirow[t]{3}{*}{ BHV7 } & $\begin{array}{c}\text { Intergro } \\
\text { upes }\end{array}$ & 1,234 & 2 & ,617 & \multirow{3}{*}{$\begin{array}{c}, 44 \\
9\end{array}$} & \multirow[t]{3}{*}{640} \\
\hline & $\begin{array}{c}\text { Intragro } \\
\text { upes }\end{array}$ & 118,205 & 86 & 1,374 & & \\
\hline & Total & 119,438 & 88 & & & \\
\hline \multirow[t]{2}{*}{ BHV8 } & $\begin{array}{c}\text { Intergro } \\
\text { upes }\end{array}$ & 1,805 & 2 & ,902 & \multirow{2}{*}{$\begin{array}{l}1,4 \\
47\end{array}$} & \multirow[t]{2}{*}{,241 } \\
\hline & Intragro & 53,633 & 86 & 624 & & \\
\hline
\end{tabular}

Allal MOKEDDEM (2021), Journal of Internet Social Networking \& Virtual Communities, DOI: $10.5171 / 2021.518860$ 


\begin{tabular}{|c|c|c|c|c|c|c|}
\hline & upes & & & & & \\
\hline & Total & 55,438 & 88 & & & \\
\hline \multirow[t]{3}{*}{ BHV9 } & $\begin{array}{c}\text { Intergro } \\
\text { upes }\end{array}$ & ,667 & 2 & ,333 & \multirow{3}{*}{$\begin{array}{c}, 44 \\
0\end{array}$} & \multirow[t]{3}{*}{,646 } \\
\hline & $\begin{array}{c}\text { Intragro } \\
\text { upes }\end{array}$ & 65,221 & 86 & ,758 & & \\
\hline & Total & 65,888 & 88 & & & \\
\hline \multirow[t]{3}{*}{ BHV10 } & $\begin{array}{c}\text { Intergro } \\
\text { upes }\end{array}$ & 2,022 & 2 & 1,011 & \multirow{3}{*}{$\begin{array}{c}, 95 \\
6\end{array}$} & \multirow[t]{3}{*}{ 389 } \\
\hline & $\begin{array}{c}\text { Intragro } \\
\text { upes }\end{array}$ & 90,967 & 86 & 1,058 & & \\
\hline & Total & 92,989 & 88 & & & \\
\hline \multirow[t]{3}{*}{ BHV11 } & $\begin{array}{c}\text { Intergro } \\
\text { upes }\end{array}$ & 1,097 & 2 & ,548 & \multirow{3}{*}{$\begin{array}{c}, 53 \\
7\end{array}$} & \multirow[t]{3}{*}{,586 } \\
\hline & $\begin{array}{c}\text { Intragro } \\
\text { upes }\end{array}$ & 87,802 & 86 & 1,021 & & \\
\hline & Total & 88,899 & 88 & & & \\
\hline \multirow[t]{3}{*}{ BHV12 } & $\begin{array}{c}\text { Intergro } \\
\text { upes }\end{array}$ & , 148 & 2 & ,074 & \multirow{3}{*}{$\begin{array}{c}, 05 \\
2\end{array}$} & \multirow[t]{3}{*}{,950 } \\
\hline & $\begin{array}{c}\text { Intragro } \\
\text { upes }\end{array}$ & 123,133 & 86 & 1,432 & & \\
\hline & Total & 123,281 & 88 & & & \\
\hline \multirow[t]{3}{*}{ BHV13 } & $\begin{array}{c}\text { Intergro } \\
\text { upes }\end{array}$ & 1,330 & 2 & ,665 & \multirow{3}{*}{$\begin{array}{c}, 89 \\
1\end{array}$} & \multirow[t]{3}{*}{,414 } \\
\hline & $\begin{array}{c}\text { Intragro } \\
\text { upes }\end{array}$ & 64,198 & 86 & ,746 & & \\
\hline & Total & 65,528 & 88 & & & \\
\hline \multirow[t]{3}{*}{ BHV14 } & $\begin{array}{c}\text { Intergro } \\
\text { upes }\end{array}$ & 1,167 & 2 & ,583 & \multirow{3}{*}{$\begin{array}{c}, 54 \\
8\end{array}$} & \multirow[t]{3}{*}{,580 } \\
\hline & $\begin{array}{c}\text { Intragro } \\
\text { upes }\end{array}$ & 91,552 & 86 & 1,065 & & \\
\hline & Total & 92,719 & 88 & & & \\
\hline \multirow[t]{3}{*}{ BHV15 } & $\begin{array}{c}\text { Intergro } \\
\text { upes }\end{array}$ & ,783 & 2 & ,392 & \multirow{3}{*}{$\begin{array}{c}, 46 \\
6\end{array}$} & \multirow[t]{3}{*}{,629 } \\
\hline & $\begin{array}{c}\text { Intragro } \\
\text { upes }\end{array}$ & 72,340 & 86 & ,841 & & \\
\hline & Total & 73,124 & 88 & & & \\
\hline \multirow[t]{3}{*}{ BHV16 } & $\begin{array}{c}\text { Intergro } \\
\text { upes }\end{array}$ & 1,906 & 2 & ,953 & \multirow{3}{*}{$\begin{array}{c}, 75 \\
5\end{array}$} & \multirow[t]{3}{*}{,473 } \\
\hline & $\begin{array}{c}\text { Intragro } \\
\text { upes }\end{array}$ & 108,588 & 86 & 1,263 & & \\
\hline & Total & 110,494 & 88 & & & \\
\hline \multirow[t]{3}{*}{ BHV17 } & $\begin{array}{c}\text { Intergro } \\
\text { upes }\end{array}$ & 1,517 & 2 & ,758 & \multirow{3}{*}{$\begin{array}{c}, 60 \\
4\end{array}$} & \multirow[t]{3}{*}{, 549} \\
\hline & $\begin{array}{c}\text { Intragro } \\
\text { upes }\end{array}$ & 107,921 & 86 & 1,255 & & \\
\hline & Total & 109,438 & 88 & & & \\
\hline \multirow[t]{2}{*}{ BHV18 } & $\begin{array}{c}\text { Intergro } \\
\text { upes }\end{array}$ & ,937 & 2 & ,469 & \multirow{2}{*}{$\begin{array}{c}47 \\
6\end{array}$} & \multirow[t]{2}{*}{ 623 } \\
\hline & Intragro & 84,591 & 86 & ,984 & & \\
\hline
\end{tabular}

Allal MOKEDDEM (2021), Journal of Internet Social Networking \& Virtual Communities, DOI : $10.5171 / 2021.518860$ 


\begin{tabular}{|c|c|c|c|c|c|c|}
\hline & upes & & & & & \\
\cline { 2 - 5 } & Total & 85,528 & 88 & & \multirow{2}{*}{1,3} & \multirow{2}{*}{, 277} \\
& $\begin{array}{c}\text { Intergro } \\
\text { upes }\end{array}$ & 2,101 & 2 & 1,051 & \multirow{2}{*}{03} & \\
\cline { 2 - 5 } & $\begin{array}{c}\text { Intragro } \\
\text { upes }\end{array}$ & 69,337 & 86 & & \\
\cline { 2 - 5 } & Total & 71,438 & 88 & & \\
\hline
\end{tabular}

Source: (SPSS)

\section{Discussion}

The behaviour of using the blue environment varies from one context to another. The purely conservative Arab context has just started to stretch and open up to the outside world. Today, all commercial, educational, cultural, industrial and even governmental activities include the social dimension in their current and future development plan. Algeria as a nation, having more than half of its population of young people under 30 years of age, is more exposed to a virtual lifestyle on social networks. This factor pushed the author to find out how Algerians behave in the face of this new trend and to know how they interact with everyone via networks.

The behaviour of using the blue environment by Algerian students is subjected to five main factors structured as follows:

- The first factor is calculated based on the expected network protection measures followed by the initial fallout.

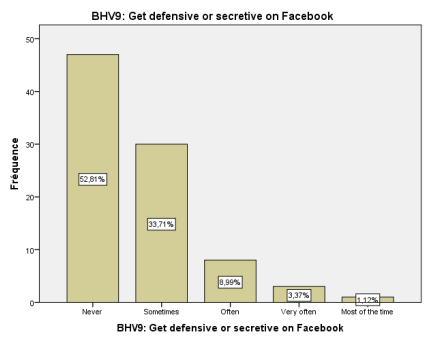

Fig. 2. Distribution of number of defensive or secret actions on Facebook, Source (SPSS)
- The second is measured by the mode of using social networks.

- The third factor presents the second level of fallout expected following the pilot actions on the network.

- The fourth factor presents the final degree of fallout.

- The fifth factor presents the time spent by the student using social networks.

The first factor presents the protection measures used on Facebook. It is found that $33.71 \%$ of the population split into two gender categories, $14.16 \%$ for men and $19.10 \%$ for women, are sometimes defensive or secret on Facebook (See Figures 2 and 3). In this context, different formulas can be implemented to properly identify the defensive or secret behavior of facebookers. According to Deptula et al. (2020), secret Facebook groups can be used as an effective platform for educational purposes. According to Stutzman and Kramer-Duffield (2010), having a Facebook profile reserved for friends can reduce interpersonal violations that can affect a person's identity.

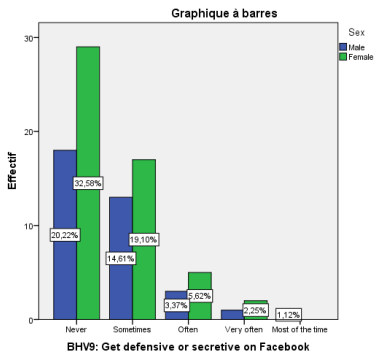

Fig. 3. Distribution of number of defensive or secret actions on Facebook according to gender,

Allal MOKEDDEM (2021), Journal of Internet Social Networking \& Virtual Communities, DOI: $10.5171 / 2021.518860$ 
In the context of other protective procedures planned, it is found that $39.33 \%$ divided into two gender categories, $23.60 \%$ for men and $15.73 \%$ for women, sometimes perform actions to block disturbing thoughts about their life and

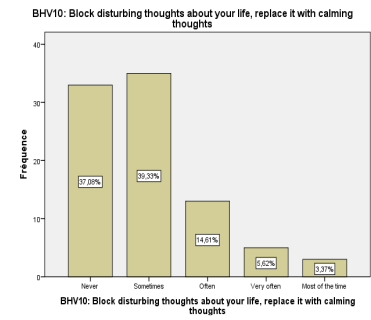

Fig. 4. Distribution of number of actions blocking disturbing thoughts about one's life and replacing them with calming thoughts, Source (SPSS)

For more protection against external threats, it is found that $42.70 \%$ divided into two gender categories, $17.98 \%$ for men and $24.72 \%$ of women, have an anticipatory character when they try to reconnect on Facebook (See Figures 6 and 7). According to Rainie et al. (2013), a set of latent factors can drive the action to induce the user to leave Facebook. It is worth mentioning that $61 \%$ of Facebook users have taken a voluntary break from using the site at some point. This action is justified in percentage via a set of items including the following:

- $21 \%$ of respondents were too busy/ did not have time to connect to Facebook.

- $10 \%$ of respondents just weren't interested/just didn't like it.

- $10 \%$ of respondents consider social media a waste of time/irrelevant content.

- $\quad 9 \%$ of respondents consider social networks as a space that brings together drama activities.

- $8 \%$ of respondents are concerned about going on vacation/travel/deployment. replace them with calming thoughts (See Figures 4 and 5). According to Gashi and Knautz (2016), hiding or unsubscribing, as well as defusing, is an online strategy used to avoid contact with others and move towards the dissolution of relationships.

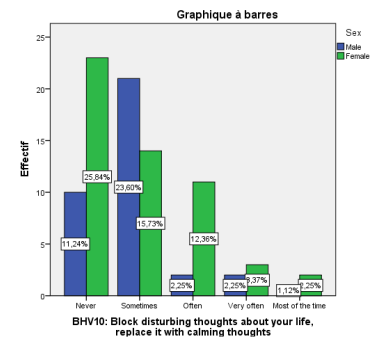

Fig. 5. Distribution of number of actions blocking disturbing thoughts about one's life and replacing them with calming thoughts according to

- $1 \%$ of respondents took a break for religious reasons.

The anticipatory task on Facebook can generate a set of relevant information that can be used in professional and academic tasks. A study was conducted by Nadkarni and Hofmann (2012) on undergraduate students at the University of Illinois where an anticipatory task was asked from students to browse a teacher's FB website and anticipate what it would be like to be in a classroom with this teacher. At this stage, the actions most frequently performed by the teacher, such as: uploading photos to social networks; respond to messages from relatives or give their opinion on certain subjects. Indeed, these actions can induce a feeling of belonging in the mind of the student and even have a deeper social information on the teacher, which helps the learners to determine the means and the style of communication with their teachers and therefore to strengthen the emotional relationship between them. 


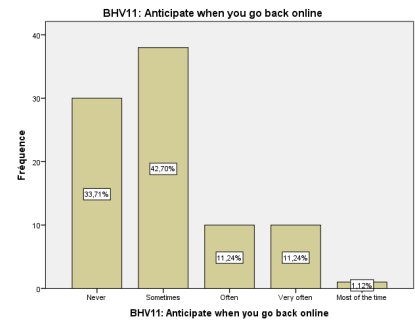

Fig. 6. Distribution of the number of anticipatory actions when they reconnect on Facebook, Source (SPSS)

The fallouts of using social networks are varied and multiple. Three aspects are presented. The first concerns the academic and professional dimension. It is found that women are more disciplined in carrying out their academic and professional tasks

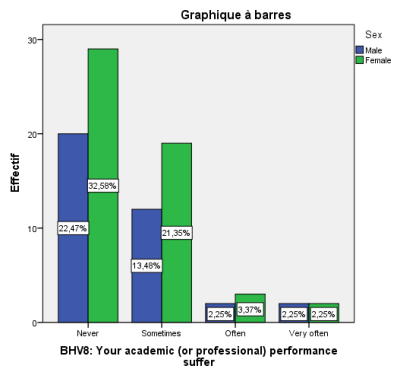

Fig 8. Distribution of the difficulty of the academic (or professional) performance according to gender, Source (SPSS)

Internationally, the effects are close to what is happening at the national level. In their study, Whelan et al. (2020) assert that excessive use of social media may require high cognitive and energetic processing. This was scientifically proven by the study conducted by Kauser and Awan (2019) on a sample of 300 postgraduate students located in the Vehari district, Pakistan. The results show that the academic performance is severely affected for the category of students who use social media as a teaching tool during the training path.

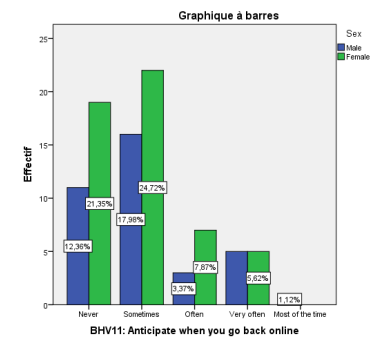

Fig. 7. Distribution of the number of anticipatory actions when they reconnect on Facebook according to gender, Source (SPSS)

than men, with a percentage of $32.58 \%$ and $22.47 \%$, respectively (See figures 8 and 9). On the other hand, household chores are sometimes more affected due to excessive consumption of Facebook network with a percentage of $28.09 \%$ among women.

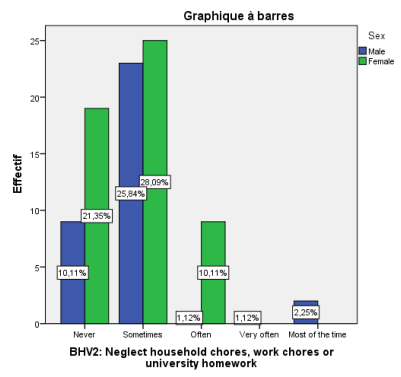

Fig. 9. Distribution of the difficulty of performing household (professional) and academic tasks according to gender, Source

The second factor is presented via a set of actions driven by the user. It is noted that $57.3 \%$ of Algerian students are sometimes confronted with developing new relationships by forming new friends. Among them, 21.35\% sometimes use the new relationships established for exchange purposes with their friends, versus 34.83\% who are not at all interested in developing a new relationship. Finally, $41.57 \%$ of users are sometimes asked to consult their posts, among them $19.10 \%$ sometimes consult 
their messages for discussion purposes between friends (See Figures 10, 11, 12

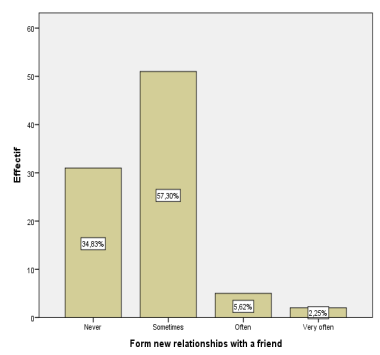

Fig. 10. Distribution of new relationships on Facebook, Source (SPSS)

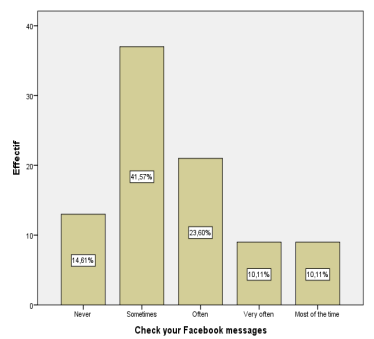

Fig. 12. Distribution of messaging consultation on Facebook, Source (SPSS) and 13).

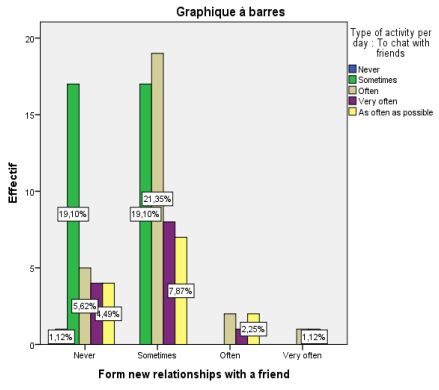

Fig. 11. Distribution of new relationships on Facebook based on discussions with friends, Source

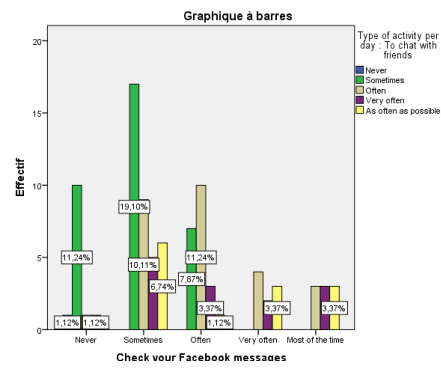

Fig. 13. Distribution of messaging consultation on Facebook based on discussions with friends, Source (SPSS)

The mode of action on Facebook differs in terms of interaction and level of excitement. The author retains that $33.71 \%$ are never excited when using Facebook, versus the same volume of the population who are sometimes excited to spend time on Facebook with their partners and friends (See Figure 14).

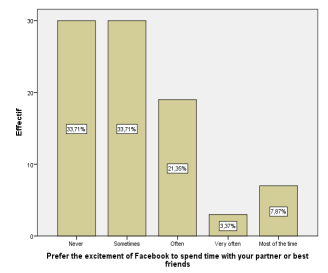

Fig. 14. Distribution of the frequency of excitement on Facebook, Source (SPSS)

In previous studies, things were not too far from what happens in the Algerian context. According to the study carried out by Brandtzæg and Heim (2009), among 5.233 users who answered the questionnaire distributed on Norwegian territory context,
$31 \%$ of users are found to be motivated to build new relationships; versus $21 \%$ of the population following their friends who are part of a community or an association. Some mention social media as a place to get some kind of support when they are

Allal MOKEDDEM (2021), Journal of Internet Social Networking \& Virtual Communities, DOI : $10.5171 / 2021.518860$ 
depressed and have suicidal thoughts. Others identify themselves as verbal pingpong spaces that enrich discussions by incorporating fruitful ideas. At most, 10\% of them are oriented to open channels of access to information, including fashion, music, politics, literature and cultural events. Finally, over $3 \%$ of users view photos and videos.

In addition, some were especially excited to check their profile to see if anyone has commented on their published content. In this context, $1.5 \%$ of users are reporting the ability to surf other users' profiles as the main reason to use Facebook. At this level, people look for other profiles in order to update the information about different people. In this case, the behaviour of using the social network develops a sense of curiosity in people. Finally, 1\%, mostly girls, indicated that the family contact was the most important reason to visit the social media.

Scientists are questioning about the behaviour of users on the social network. Is it connected to socio-professional contexts? In the academic context, the class of students does not behave away from other categories. According to Mese and Aydin (2019), in a study carried out with undergraduates from various faculties of a Turkish public university, the authors identified three main factors that contribute to the development of user behaviour when using Facebook.

The first factor is presented in the communication section where there was a significant difference between different platforms. According to the test Post-Hoc of Scheffe, participants differ in terms of communication in relation to the variety of social platforms. In conclusion, both Instagram and WhatsApp environments received more usage in terms of communication compared to Facebook. The second factor is presented by sharing content on Facebook. According to the test Post-Hoc of Scheffe, the Instagram environment is more preferred than WhatsApp and Facebook. The third factor is presented by entertainment. It is found that the Instagram environment is used more for entertainment than WhatsApp and Facebook.

The second important aspect that can affect a relationship between the users and the blue environment is presented by the complaint of relatives and friends due to the time spent on Facebook. It is noted that $44.94 \%$ of Algerian students have never received any criticism from others about the abusive time spent on Facebook, versus $32.58 \%$ who are sometimes confronted with similar situations (See figure 15). This demonstration was confirmed by Jha et al. (2016) via the study conducted with dental medicine students. The study revealed that $86.7 \%$ of the users said they were annoyed when someone disturbed them while using Facebook. Among respondents, 13.5\% said that their friends and family frequently complained about spending time on Facebook, while $24.3 \%$ of participants agreed that it was difficult not to connect to Facebook for one whole day. Meanwhile, in Algeria, among a sample of 89 students, it is found that $30.13 \%$ of them sometimes experience a situation of a boring, empty and joyless feeling when they are far from being active on the blue environment (See figure 16). 


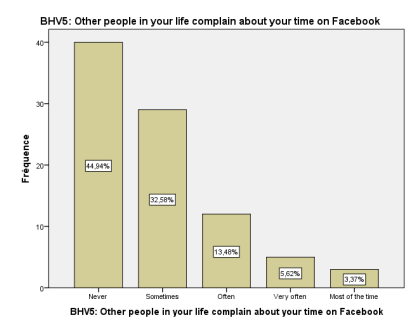

Fig. 15. Distribution of the percentage of complaints retained following abuse Facebook consumption, Source (SPSS)

As for the average time spent by Algerian students on social media, this study indicates that $31.45 \%$ use Facebook when they have more free time or nothing else to do. $45 \%$ never think about spending time on Facebook when they are not connected. At the same time, $49.4 \%$ are sometimes confronted with saying "I add a few more minutes on Facebook". In compliance, the majority of students, estimated at $42.7 \%$, sometimes seek to reduce the time they spend on Facebook.

It is estimated that $60.7 \%$ of Algerian students never think of spending more time on Facebook than spending time with others. This rule takes on a different

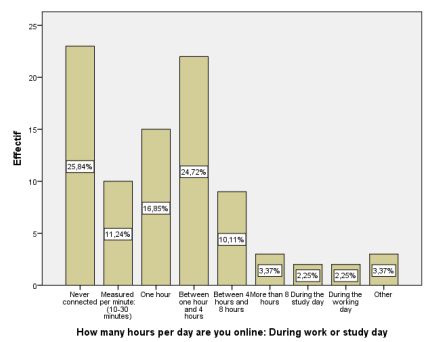

Fig. 17. Distribution of time consumed during the work and study session, Source

Regarding the gender aspect, $22.47 \%$ of women are more disciplined than men in terms of not being online during the study session or the work period. At most, $44.94 \%$ of women prefer to spend their free time away from social networks,

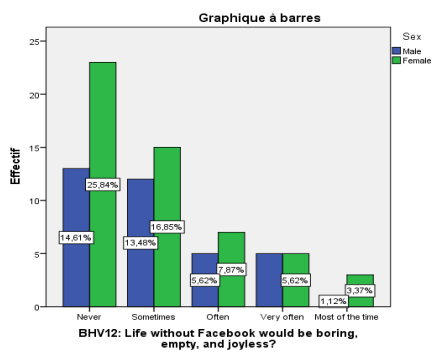

Fig. 16. Distribution of percentage of feelings: Boredom, emptiness, and joylessness according to gender, Source

disposition with adolescents. In the study conducted by ÜNAL (2018) among Facebook users living in Kütahya, Turkey, with a sample made up of primary schools, high schools, vocational schools and educational centers in Kütahya, it is shown that $67.9 \%$ of participants connect to Facebook in the presence of their family, while $32.1 \%$ prefer otherwise.

It is found that $25.84 \%$ of Algerian students are never connected to the network during the study session or the period of work. In addition, $68.54 \%$ of students will never be concerned about social media in their free time (See figures 17 and 18).

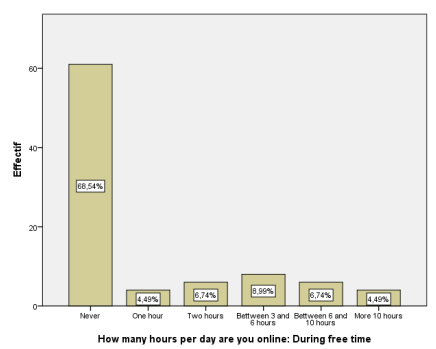

Fig. 18. Distribution of time consumed during free time, Source (SPSS)

versus $23.60 \%$ of men who prefer otherwise (See Figures 19 and 20). 


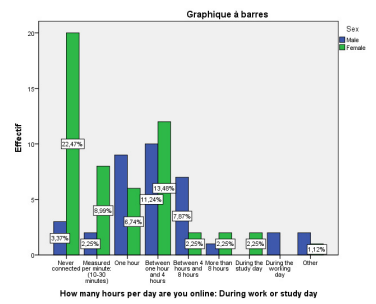

Fig. 19. Distribution of time consumed during the work and study session according to gender, Source cmen

When it comes to the frequency of hours spent online things are a bit close. Huang's study (2017) asserts that $28 \%$ of the time spent online is consumed on social networks. Now, the users spend an average of 2 hours and 24 minutes per day working in a multi-network on an average of eight interfaces (Facebook, Instagram, WhatsApp, etc.) followed by messaging apps (Smart insights, 2020).

A study conducted by MACIT and MACIT (2018) in Turkey indicates that the average time spent on social networks is estimated at 2 hours 48 minutes. In this context, different means are used for interaction,

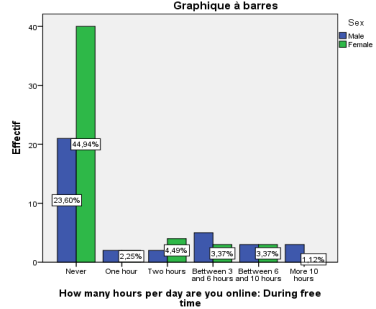

Fig. 20. Distribution of time consumed during free time according to gender, Source (SPSS)
$50.7 \%$ dedicated to social media and $15.3 \%$ to emails. In contrast, $24.72 \%$ of Algerian students spend their time on Facebook for a period between one and four hours (See figure 18). In this context, different means are used for varied interactions according to gender such as: Viber with an estimated usage percentage at $71.91 \%$, distributed between $23.60 \%$ used by men versus $48.31 \%$ by women; WhatsApp Messenger with an estimated usage percentage at 18.0\%; Twitter with an estimated usage percentage at 5.6\%; and Skype with an estimated usage percentage at $4.5 \%$ (See Figure 21).

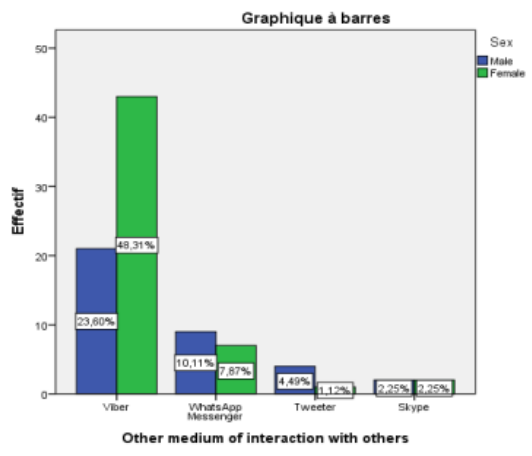

Fig. 21. Other means of interacting with others according to gender, Source (SPSS)

The third fallout is manifested in the user's state of health, which can be affected by excessive use of the Facebook network. As a result, $37.1 \%$ of respondents said that sometimes their sleep is disturbed during the night. In contrast, $40.4 \%$ were never affected when using the blue environment (See figure 22). 


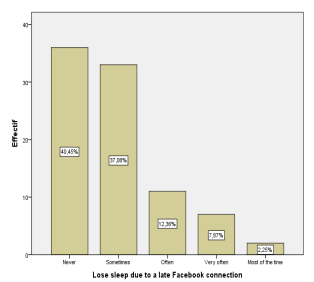

Fig. 22. Distribution of percentage or sıeep loss aue to late racebook login, Source (SPSS)

This demonstration is approved by several studies conducted to analyze the impact of social networks on the quality of sleep. The study conducted by Long Xu et al. (2015) emphasizes a cross-sectional diagnosis that was carried out on undergraduate students in Chongqing, China. The result indicates that more than half of the undergraduates who use social media have poor quality of sleep. Moreover, according to the study conducted in the US by Levenson et al. (2016) on a sample of 1788 individuals including young adults aged between 19 to 32 years, the volume and frequency of social media were evaluated based on the self-reported minutes per day spent in the blue environment. The test was done in the city of Pittsburgh and provided a strong association between the utilization of social media and sleep disorders. This was endorsed in a study carried out by Coyne et al. (2020) who found a link between times spent using social media and mental health problems, such as depression and anxiety.

\section{Conclusion}

The Arab context, and particularly the Algerian context, overlaps other contexts in the world, especially in the generic use of social networks. The use of social networks is distinct with respect to demographic factors such as location, occupation, family status and education level ... etc.

This study examines how Algerian students behave in the face of the blue environment. During this study, the researcher faced difficulty in collecting the necessary number of respondents due to the Covid19 pandemic where direct contact with students has become a bit complicated because of interruptions in the face-to-face study in the period from March to September, 2020.

The generic behaviour of Algerian students on the network is presented through three dimensions. The first dimension is presented by "the protective actions carried out by the user". This action generates, in the mind of the user, an attitude of reserve and prudence about any activity on Facebook (publications, advertisements, story and online broadcast). At this point, the users seek to develop a relationship of loyalty with their virtual environment.

The second dimension is presented by "the mode of using the social networks". In this regard, each user develops attitudes which give signs of presence on the network. At this level, the user feels his presence and values his contributions in this virtual world.

The third dimension is presented by "the time reserved by the student to use social networks". This dimension develops the temporal attitudes of the user who manages the circumstantial activities on Facebook. For example: publishing a story on Facebook joints the user to the blue environment to login in time before the expiration of the publication.

This study offers academics and managers of higher education institutions (teachers, managers, deans, academic advisors and digital advisors, etc...) the opportunity to develop informational content on Facebook that will reflect the most frequent set of behaviour followed and the attitude developed by users. In subsequent studies, the author will develop informational 
content on Facebook in collaboration with the staff of the University of Algiers 3 in Algeria relying on all behavioural information generated by Algerian students on Facebook.

\section{References}

- Anspach, NM. (2017)'The new personal influence: How our Facebook friends influence the news we read,'Political Communication, 34(4), 590-606.

- Blog Medianet., (2016), "Chiffres clés de Facebook en Algérie,' [Online], [RetrievedJuly 10, 2020], https://blog.medianet.tn/blog/chiffres -cles-de-facebook-en-algerie-0

- Brandtzæg, PB. and Heim, J. (2009),'Why people use social networking sites'Proceedings of the International conference on online communities and social computing, 2009, Springer, Berlin, Heidelberg, 143-152.

- $\quad$ Błachnio, A., Przepiorka, A., Bałakier, E. and Boruch, W. (2016),'Who discloses the most on Facebook?,'Computers in Human Behavior, 55, 664-667.

- Childers, CC and Levenshus, AB. (2016),'Bringing the digital world to students: partnering with the university communications office to provide social media experiential learning projects,'Communication Teacher, 30(4), 190-194.

- Chin, CY., Lu, HP.and Wu, CM. (2015),'Facebook users' motivation for clicking the "like" button,'Social Behavior and Personality: an international journal, 43(4), 579-592.

- Coyne, SM., Rogers, AA.,Zurcher, JD., Stockdale, L.and Booth, M. (2020),'Does time spent using social media impact mental health?: An eight year longitudinal study,'Computers in Human Behavior, 104, 106160.

- Cvijikj, IP., Spiegler, ED. and Michahelles, F. (2011),'The effect of post type, category and posting day on user interaction level on Facebook' In 2011 IEEE Third International Conference on Privacy, Security, Risk and Trust and 2011 IEEE Third International Conference on Social Computing,IEEE, 810-813.

- Debatin, B., Lovejoy, JP., Horn, AK.and Hughes, BN. (2009),'Facebook and online privacy: Attitudes, behaviors, and unintended consequences,'Journal of computer-mediated communication, 15(1), 83-108.

- Deptula, PL., Auten, B. and Chang, J. (2020),'Use of Social Media to Teach Global Reconstructive Surgery: Initiation of a Secret Facebook Group,' Plastic and Reconstructive Surgery Global Open, 8(3).

- Facebook., (2018), "How Facebook AI Helps Suicide Prevention,' [Online], [Retrieved July 06, 2020], https://about.fb.com/news/2018/09/i nside-feed-suicide-prevention-and-ai/

- Facebook., (2019), "Second Quarter 2018 Results Conference Call,' [Online], [Retrieved Juin 18, 2020], https://s21.q4cdn.com/399680738/fil es/doc_financials/2018/Q2/Q218earnings-call-transcript.pdf

- Facebook., (2020), "Facebook Reports First Quarter 2020 Results,' [Online], [Retrieved Juin 18, 2020], https://s21.q4cdn.com/399680738/fil es/doc_news/Facebook-Reports-FirstQuarter-2020-Results-2020.pdf

- Financial Times., (2019), "Can Facebook really rely on artificial intelligence to spot abuse?,' [Online], [Retrieved July 05, 2020], https://www.ft.com/content/69869f3 a-018a-11ea-b7bc-f3fa4e77dd47

- FredCavazza., (2010), "Comment les nouvelles règles de Facebook vont modifier le comportement des utilisateurs,' [Online], [Retrieved July 14 , 2020], https://s21.q4cdn.com/399680738/fil es/doc_news/Facebook-Reports-FirstQuarter-2020-Results-2020.pdf

- Fullwood, C., James, BM. and ChenWilson, CH. (2016),'Self-concept clarity and online self-presentation in adolescents,'Cyberpsychology,

Behavior, and Social Networking, 19(12), 716-720.

Allal MOKEDDEM (2021), Journal of Internet Social Networking \& Virtual Communities, DOI: $10.5171 / 2021.518860$ 
- Gashi, Land Knautz, K. (2016),'Unfriending and becoming unfriended on Facebook,'1-44.

- Gerbaudo, P., Marogna, F. and Alzetta, C. (2019), 'When Positive Posting Attracts Voters: User Engagement and Emotions in the 2017 UK Election Campaign on Facebook,'Social Media+ Society, 5(4), 2056305119881695.

- Halder, UK and Khatun, J. (2018),'SelfConcept and Attitude towards the Use of Facebook: A Study on the PostGraduate Students,'.

- Huang, C. (2017)'Time spent on social network sites and psychological wellbeing: A meta-analysis,' Cyberpsychology, Behavior, and Social Networking, 20(6), 346-354.

- Ibrahim, SZ.,Blandford, A.and BianchiBerthouze, N. (2012),'Privacy settings on Facebook: Their roles and importance' In 2012 IEEE International Conference on Green Computing and Communications,IEEE, 426-433.

- JDN., (2020), "Nombre d'utilisateurs de Facebook dans le monde,' [Online], [Retrieved Juin 18, 2020], https://www.journaldunet.com/ebusi ness/le-net/1125265-nombre-dutilisateurs-de-facebook-dans-le monde/\#: :text=Au\%20premier\%20t rimestre $\% 202020 \% 2 \mathrm{C} \% 20$ Facebook,c haque $\% 20$ jour $\% 20$ dans $\% 20 \mathrm{le} \% 20$ mo nde.

- Jha, RK., Shah, DK., Basnet, S., Paudel, KR., Sah, P., Sah, AK. andAdhikari, K. (2016),'Facebook use and its effects on the life of health science students in a private medical college of Nepal,'BMC research notes, 9(1), 378.

- Jordan, PJ.,Nigg, CR., Norman, GJ., Rossi, JS. andBenisovich, SV. (2002),'Does the transtheoretical model need an attitude adjustment?: Integrating attitude with decisional balance as predictors of stage of change for exercise,'Psychology of Sport and Exercise, 3(1), 65-83.

- Jędruszczak, K. 'Prywatnośćjakopotrzeba ramachkoncepcjisiebie,'RocznikiPsycho logiczne, 8(2), 111-135.
- $\quad$ Kauser, S and Awan, AG (2019),'Impact de l'utilisation des médias sociaux sur la performance académique des étudiants au niveau des cycles supérieurs: preuves du Pakistan,'Global Journal of Management, Social Sciences and Humanities , 5 (1), 116-142.

- Kent, ML andTaylor, M. (2016),'From Homo Economicus to Homo dialogicus: Rethinking social media use in CSR communication,'Public Relations Review, 42(1), 60-67.

- Levenson, JC.,Shensa, A., Sidani, JE., Colditz, JB. andPrimack, BA. (2016), 'The association between social media use and sleep disturbance among young adults,'Preventive medicine, 85, 36-41.

- MACIT, G. and MACITT.BH. (2018),'Affects of Social Media Addiction: A Survey' Conference: INES 2018At: Antalya, Turkey.

- Mese, C and Aydin, GS. (2019), 'The Use of Social Networks among University Students,'Educational Research and Reviews, 14(6), 190-199.

- Mettler, T. (2018)'Contextualizing a professional social network for health care: Experiences from an action design research study,'Information Systems Journal, 28(4), 684-707.

- Moolenaar, NM.,Sleegers, PJ. and Daly, AJ. (2012),'Teaming up: Linking collaboration networks, collective efficacy, and student achievement,'Teaching and teacher education, 28(2), 251-262.

- Nadkarni, Aand Hofmann, SG. (2012),'Why do people use Facebook?,'Personality and individual differences, 52(3), 243-249.

- Nason, KN., Byrne, H., Nason, GJ. and O'connell, B. (2018),'An assessment of professionalism on students' Facebook profiles,'European Journal of Dental Education, 22(1), 30-33.

- Nunes, RH., Ferreira, JB., de Freitas, AS. and Ramos, FL. (2018),'The effects of social media opinion leaders' recommendations on followers' intention to buy,'RevistaBrasileira de Gestão de Negócios, 20(1), 57-73. 
- Nunnally, JC. (1978)'An overview of psychological measurement,'Clinical diagnosis of mental disorders, 97-146.

- Nyangeni, T., Du Rand, S. and Van Rooyen, D. (2015), 'Perceptions of nursing students regarding responsible use of social media in the Eastern Cape,' Curationis, 38(2), 1-9.

- Padyab, A.,Päivärinta, T., Ståhlbröst, A.and Bergvall-Kåreborn, B. (2016),'Facebook users attitudes towards secondary use of personal information,'.

- $\quad$ Race to the bottom., (2007), "Privacy ranking of internet service companies-A consultation report,' [Online], [Retrieved September 15, 2007],

https://privacyinternational.org/sites /default/files/2017-

12/A_Race_Bottom.pdf

- Rainie, L., Smith, A. and Duggan, M. (2013),'Coming and going on Facebook,'Pew Research Center's Internet and American Life Project.

- $\quad$ Ross, JG and Myers, SM. (2017),'The current use of social media in undergraduate nursing education: a review of the literature,' CIN: Computers, Informatics, Nursing, 35(7), 338-344.

- Schäfer, S. (2020)'Illusion of knowledge through Facebook news? Effects of snack news in a news feed on perceived knowledge, attitude strength, and willingness for discussions,'Computers in Human Behavior, 103, 1-12.

- $\quad$ Shestak, V., Gura, A., Borisova, U. and Kozlovskaya, S. (2020),'Social Networks as a Means of Professional Communication,'Journal of Talent Development and Excellence, 12(2s), 1402-1412.

- Smartinsights., (2020), "Global social media research summary July 2020,' [Online], [Retrieved September 28, 2020],

https://www.smartinsights.com/social -media-marketing/social-mediastrategy/new-global-social-mediaresearch/\#: :text=Social\%20media\% 20users\%20are\%20now,10\%20digital
$\% 20$ marketing\%20statistics $\% 20$ sourc es.

- $\quad$ Stieglitz, S., Bunker, D., Mirbabaie, M. and Ehnis, C. (2018),'Sense-making in social media during extreme events,'Journal of Contingencies and Crisis Management, 26(1), 4-15.

- Stutzman, F. and Kramer-Duffield, J. (2010),'Friends only: examining a privacy-enhancing behavior in facebook'In Proceedings of the SIGCHI conference on human factors in computing systems, 1553-1562.

- Tartaglia, S. (2016)'Different modalities of using Facebook: The influence of actual social relations, wellbeing, and attitude towards the medium,'.

- Tran, H. and Shcherbakov, M. (2016),'Detection and prediction of users attitude based on real-time and batch sentiment analysis of facebook comments' In International conference on computational social networks, Springer, Cham, 273-284.

- $\quad$ Trust, T., Krutka, DG. and Carpenter, JP. (2016),'Together we are better: Professional learning networks for teachers,'Computers \& education, 102, 15-34.

- ÜNAL, S. (2018)'The Effect of Social Media Use to The Time Spent With Family Members,'Pamukkale University, International Journal of Eurasia Social Sciences, Vol: 9, Issue: 31, pp. (550-578).

- Whelan, E., Islam, AN. and Brooks, S. (2020),'Appliquer le paradigme SOBC pour expliquer comment la surcharge des médias sociaux affecte les performances

académiques,'Informatique et éducation, 143 , 103692.

- Xu, LX., Zhu, RZ., Sharma, M.and Zhao, Y. (2015),'The influence of social media on sleep quality: a study of undergraduate students in Chongqing,'. J Nurs Care,China, 4(253), 2167-1168.

- Yates, D and Paquette, S. (2011),'Emergency knowledge management and social media technologies: A case study of the 2010 Haitian earthquake,'International

Allal MOKEDDEM (2021), Journal of Internet Social Networking \& Virtual Communities, DOI: $10.5171 / 2021.518860$ 
journal of information management, 31(1), 6-13.

Appendix: Survey

Section A: A few words about you

Gender: Male; Female.

What is your age?

What is your main occupation?

Student; Civil servant; Unemployed; In the business.

Would you say using Facebook is expensive, given your monthly budget?

Not at all expensive; A little expensive; Very expensive.

Your location:

Downtown; Far from the city center.

Do you use any other medium of interaction with others more than Facebook?

Twitter; Skype; Viber; WhatsApp Messenger; Others.

Section B: Can you describe your actual use of Facebook?

B1. How long have you been using Facebook?

How many months?

How many years?

B2. Most of the time, what do you use Facebook on?

What is your usage medium?

Smartphone; I-pad or another brand; Laptop; Desktop at home; Desktop elsewhere.

B3. When you are online (whatever the device), how would you rate your connection to Facebook?

Your moment of connection: As soon as possible; When I open the device; As soon as I finish other tasks; If I have nothing else to do.

B4. When you use the Internet in an Internet cafe, what is the main reason you rent a computer?

I need to get information from the browser outside Facebook.

I want to chat using Skype or Messenger or another instant messaging system outside Facebook.

I want to use Facebook.

I want to listen to music outside Facebook.

I want to play games outside Facebook.

Others

Allal MOKEDDEM (2021), Journal of Internet Social Networking \& Virtual Communities, DOI : $10.5171 / 2021.518860$ 
B5. How often do you perform the following function on Facebook per day?

- Look at your profile:

Never; Sometimes; Often; Very often; As often as possible

- Chat with friends:

Never; Sometimes; Often; Very often; As often as possible

- Upload photos:

Never; Sometimes; Often; Very often; As often as possible

- Search people:

Never; Sometimes; Often; Very often; As often as possible

- Read comments posted on your wall:

Never; Sometimes; Often; Very often; As often as possible

- Read comments on your photos:

Never; Sometimes; Often; Very often; As often as possible

- To play games:

Never; Sometimes; Often; Very often; As often as possible

- Find information about friends or other people:

Never; Sometimes; Often; Very often; As often as possible

- Get updates on friends' activities:

Never; Sometimes; Often; Very often; As often as possible

Section C: Your attitude and behavior towards Facebook

C1. For each of the following statements, please indicate your level of agreement.

- How often do you find that you are staying on Facebook longer than expected?

Never; Sometimes; Often; Very often; Most of the time

- How often do you neglect household chores, work chores or college homework to spend more time on Facebook?

Never; Sometimes; Often; Very often; Most of the time

- How often do you prefer the excitement of Facebook to spending time with your partner or best friends?

Never; Sometimes; Often; Very often; Most of the time

- How often do you form new relationships with a friend found on Facebook?

Never; Sometimes; Often; Very often; Most of the time

- How often do other people in your life complain about your time spent on Facebook?

Never; Sometimes; Often; Very often; Most of the time

- How often does your schoolwork or job suffer from your time spent on Facebook?

Never; Sometimes; Often; Very often; Most of the time

- How often do you check your Facebook messages before doing anything else you need to do?

Never; Sometimes; Often; Very often; Most of the time

C2. For each of the following statements, please indicate your level of agreement.

Allal MOKEDDEM (2021), Journal of Internet Social Networking \& Virtual Communities, DOI: $10.5171 / 2021.518860$ 
- How often does your academic (or professional) performance suffer from your use of Facebook?

Never; Sometimes; Often; Very often; Most of the time

- How often do you get defensive or secretive when someone asks you what you're doing on Facebook?

Never; Sometimes; Often; Very often; Most of the time

- How often do you block disturbing thoughts about your life with calming thoughts on Facebook?

Never; Sometimes; Often; Very often; Most of the time

- How often do you anticipate when to get back online?

Never; Sometimes; Often; Very often; Most of the time

- How often do you think life without Facebook would be boring, empty, and joyless?

Never; Sometimes; Often; Very often; Most of the time

- How often do you slam, scream, or act in annoyance if someone bothers you while you're on Facebook?

Never; Sometimes; Often; Very often; Most of the time

- How often do you lose your sleep due to a late connection to Facebook?

Never; Sometimes; Often; Very often; Most of the time

C3. For each of the following statements, please indicate your level of agreement.

- How often do you feel concerned about Facebook when you are not logged in or wondering how to log in?

Never; Sometimes; Often; Very often; Most of the time

- How often do you find yourself saying "just a few more minutes" on Facebook?

Never; Sometimes; Often; Very often; Most of the time

- How often do you try cutting down on your time spent on Facebook and fail?

Never; Sometimes; Often; Very often; Most of the time

- How often do you try to hide nearby how long you've been on Facebook?

Never; Sometimes; Often; Very often; Most of the time

- How often do you choose to spend more time on Facebook rather than hanging out with others?

C4) How many hours do you spend online (logged in) on Facebook per day?

- How many hours during work or study day?

- How many hours during free time?

After answering this questionnaire, would you say that your opinion on Facebook:

Exactly the same;

The same but a few questions made me think about my behaviour

How did you find out about this questionnaire?

OIn class

A colleague

OThrough Facebook

Allal MOKEDDEM (2021), Journal of Internet Social Networking \& Virtual Communities, DOI : $10.5171 / 2021.518860$ 